\title{
Neo- and Paleo-Limnological Studies on Diatom and Cladoceran Communities of Subsidence Ponds Affected by Mine Waters (S. Poland)
}

\author{
Agnieszka Pociecha ${ }^{1, * \mathbb{D}}$, Agata Z. Wojtal ${ }^{1}$, Ewa Szarek-Gwiazda ${ }^{1}$, Anna Cieplok ${ }^{2}$, \\ Dariusz Ciszewski ${ }^{3}$ and Sylwia Cichon ${ }^{3}$ \\ 1 Department of Freshwater Biology, Institute of Nature Conservation, Polish Academy of Sciences, Adama \\ Mickiewicza Av. 33, 31-120 Kraków, Poland; wojtal@iop.krakow.pl (A.Z.W.); szarek@iop.krakow.pl (E.S.-G.) \\ 2 Faculty of Natural Sciences, Institute of Biology, Biotechnology and Environmental Protection, University of \\ Silesia, Bankowa St. 9, 40-007 Katowice, Poland; anna.cieplok@us.edu.pl \\ 3 Faculty of Geology, Geophysics and Environmental Protection, University of Science and Technology AGH, \\ Adama Mickiewicza Av.30, 30-059 Kraków, Poland; ciszewski@geol.agh.edu.pl (D.C.); \\ scichon@agh.edu.pl (S.C.) \\ * Correspondence: pociecha@iop.krakow.pl
}

Received: 16 April 2020; Accepted: 29 May 2020; Published: 2 June 2020

check for updates

\begin{abstract}
Plankton assemblages can be altered to different degrees by mining. Here, we test how diatoms and cladocerans in ponds along a river in southern Poland respond to the cessation of the long-term $\mathrm{Pb}-\mathrm{Zn}$ mining. There are two groups of subsidence ponds in the river valley. One of them (DOWN) was contaminated over a period of mining, which ceased in 2009, whereas the other (UP) appeared after the mining had stopped. We used diatoms and cladocerans (complete organisms in plankton and their remains in sediments) to reveal the influence of environmental change on the structure and density of organisms. The water of UP pond was more contaminated by major ions $\left(\mathrm{SO}_{4}{ }^{2-}, \mathrm{Cl}^{-}\right)$and nutrients $\left(\mathrm{NO}_{3}{ }^{-}, \mathrm{PO}_{4}{ }^{3-}\right)$ than the DOWN ponds. Inversely, concentrations of $\mathrm{Zn}$, $\mathrm{Cd}, \mathrm{Cu}$ and $\mathrm{Pb}$ were significantly higher in sediment cores of DOWN ponds in comparison to those in the UP pond. Ponds during mining had higher diversity of diatoms and cladocerans than the pond formed after the mining had stopped. CCA showed that diatom and cladoceran communities related most significantly to concentrations of $\mathrm{Pb}$ in sediment cores. Comparison of diatom and cladoceran communities in plankton and sediment suggests significant recovery of assemblages in recent years and reduction of the harmful effect of mine-originating heavy metals. Some features of ponds such as the rate of water exchange by river flow and the presence of water plants influenced plankton communities more than the content of dissolved heavy metals.
\end{abstract}

Keywords: $\mathrm{Zn}-\mathrm{Pb}$ mine; subsidence ponds; physico-chemical water variables; subfossil; Cladocera; diatoms; heavy metals; CCA analyses; anthropogenic impact

\section{Introduction}

Mining industry influences the aquatic environment. Among environmental effects, draining of mines and mine tailings as well as leaching of spoil heaps have been recognized as particularly harmful for aquatic organisms. The impact of such pollution can be the most distinct in small catchments, receiving large amounts of mine drainage where dilution with natural waters is limited. Mine waters usually contain many compounds in potentially harmful amounts, inducing synergistic effects on organisms [1-4]. For example, heavy metals $(\mathrm{Cu}, \mathrm{Pb}, \mathrm{Zn})$ could be less toxic for biota in water (e.g., Cladocera) at high content of cations like $\mathrm{Ca}^{2+}$ and $\mathrm{Mg}^{2+}[5,6]$. It was also found that in systems with 
elevated metal concentrations and acidic $\mathrm{pH}$, species richness decreases and the number of taxa is low $[4,7-9]$.

Chemical quality of water bodies (e.g., lakes, rivers, dam reservoirs) receiving mining waters has been monitored in many aquatic systems, but their long term ecological impacts are only rarely estimated. Most data show a negative effect of pollution (especially by heavy metals) on planktonic organisms $[4,10]$. However, some observations show that algae and zooplankton can adapt to prolonged heavy metal contamination e.g., [11-14]. For example, in small fishponds in a partially reclaimed area impacted by the lead-zinc mine Matylda (southern Poland, Chrzanów area), the influence of heavy metals remains a minor factor, although small amounts of teratogenic forms of pyto- and zooplankton have been found $[12,13]$.

Sediments from lakes are environmental libraries, abundant in information about the history of catchments and their ecosystems. Paleolimnological studies of these sediments polluted by mining, can help to reconstruct changes of environmental conditions. As a rule, sedimentary geochemistry and associated subfossil remains of biological communities (e.g., cladoceran crustacea, diatom algae) are used to assess the natural pre-disturbance variability, the impact of the disturbance and post-disturbance dynamics $[4,15]$. Based on ecological preferences of particular organisms they can be used to assess the impacts of pollution on biological communities $[4,16]$. Because of different habitat preferences, biological remains of taxa can be sources of information about differences between depositional subenvironments and their changes over time (e.g., [4,17]).

Diatoms and cladocerans are most often used as indicators in paleoenvironmental reconstructions because of good preservation of chitinous and siliceous cell walls and well-established environmental preferences of a number of taxa $[4,18]$. Diatoms are a base element of trophic food chain with observed biomagnification of heavy metals [19]. They are good bioindicators of metal toxicity in fluvial and lentic systems [15,19-22]. Diatoms and cladocerans have great potential in paleolimnological pollution studies because of their sensitivity to changes in water quality and their location at the basis of food-webs. Heavily impacted aquatic environments can be dominated by metal-resistant diatoms and cladocerans species or with species of broad ecological tolerance [4].

The aim of our study is to recognize changes in the species composition of diatoms and cladocerans in response to $\mathrm{Zn}-\mathrm{Pb}$ mining cessation, recorded in water and bottom sediments of subsidence ponds situated on the Chechło River floodplain (southern Poland). We compared these communities in subsidence ponds active during the period of mining and in a subsidence pond inundated after the mining cessation assuming that the younger one will be less polluted with heavy metals. The first hypothesis assumes that diatom and cladoceran communities are not affected by concentration of heavy metals in water of subsidence ponds. The second hypothesis assumes that regeneration of the diatom and cladoceran communities are influenced by high heavy metal concentrations in the sediments of ponds in the river valley downstream of the mine waters discharge. The present study may be a key to understanding factors controlling ecosystem recovery from long-term disturbance. We address this by comparison of diatoms and cladocerans species living in water with their past communities using remains preserved in sediments of subsidence ponds and by correlation of their composition with present water physico-chemical variables and records of metal contamination in sediments.

\section{Materials and Methods}

\subsection{Study Area}

The ponds are situated in the middle course of the Chechło River. This area was impacted by the discharge of mine waters from a $\mathrm{Zn}-\mathrm{Pb}$ mine (Trzebionka) and by the other industrial and municipal sewage from the two towns, Trzebinia and Chrzanów [23,24]. Over the investigated period, $\mathrm{Zn}-\mathrm{Pb}$ mine was the dominating source of heavy metals in this river system whereas pollution from the two towns continued despite some variability [23]. We distinguished two research areas about $1 \mathrm{~km}$ apart: a large subsidence pond that emerged after the closure of the mine (UP) and several subsidence depressions ponded during the peak of the ore exploitation (DOWN) (Figure 1). Their areas range 
from 0.5 to ca. 5 ha and the average depth ranges between 1 and $2 \mathrm{~m}$. Some (ca. 20-50\%) of the ponds are overgrown with macrophytes.
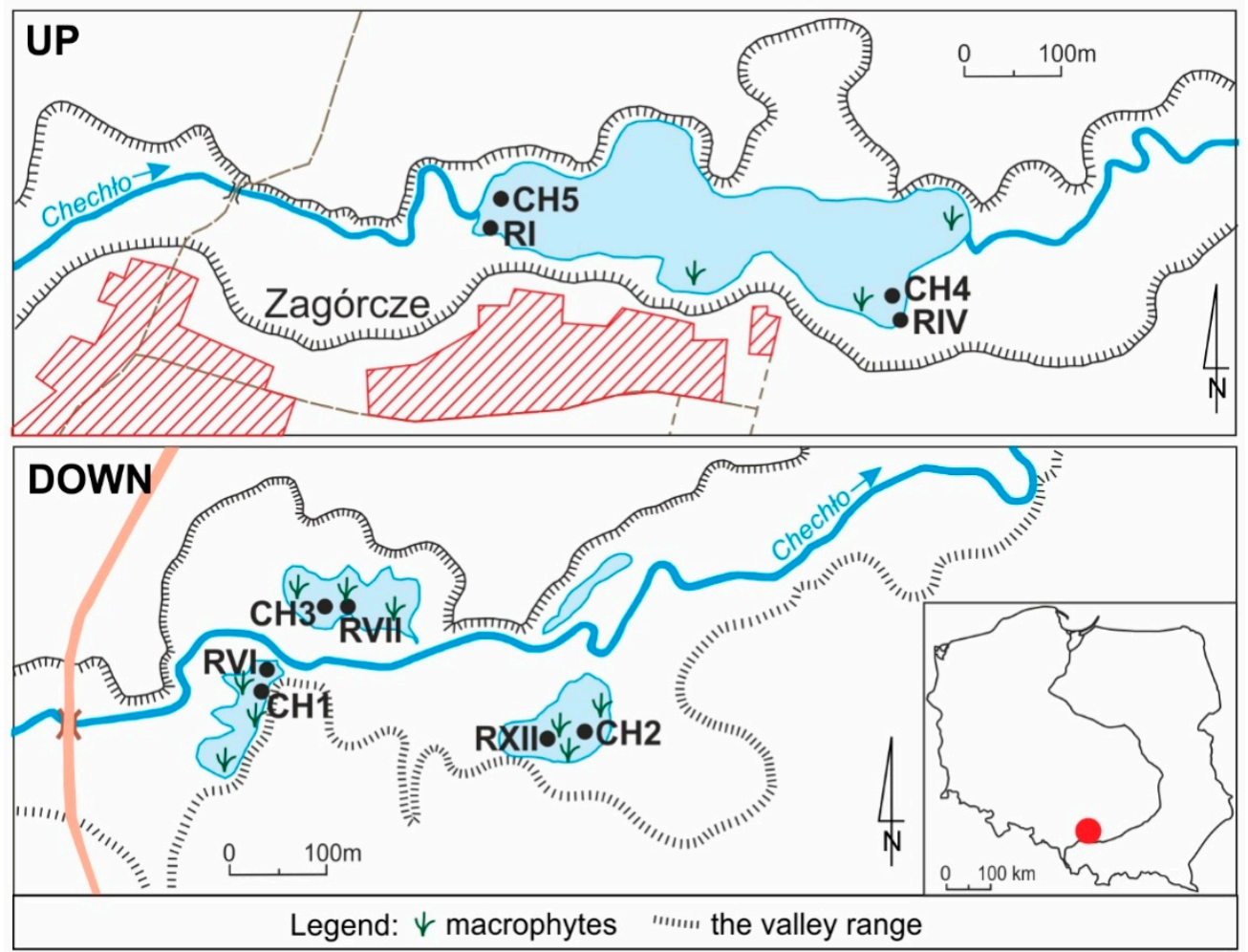

Figure 1. Sampling area-UP: Subsidence pond formed after the mine closure: water and plankton samples- $\mathrm{CH} 4, \mathrm{CH} 5$, and sediment cores: RI, RIV; DOWN: Subsidence ponds formed during peak exploitation: water and plankton samples- $\mathrm{CH} 1, \mathrm{CH} 2, \mathrm{CH} 3$ and sediment cores: RVI, RVII, RXII.

\subsection{Sampling and Measurements}

Samples for water, diatom, and cladoceran analyses were taken from sites $\mathrm{CH} 1, \mathrm{CH} 2, \mathrm{CH} 3$ (DOWN ponds), $\mathrm{CH} 4$ and $\mathrm{CH} 5$ (UP pond) four times a year (April, July, September and October 2016) (Figure 1). Core samples (UP pond: RI, RIV; DOWN pond: RVI, RVII, RXII) for heavy metals concentration, diatoms, and cladocerans were taken once in 2016, close to the same sites where water and plankton samples were collected (Figure 1). Cores were sampled using a multisampler piston corer with diameter $4.5 \mathrm{~cm}$ (Eijkelkamp, Giesbeek, Netherlands). The methodology for developing samples of collected cores is described in Pociecha et al. [25].

\subsubsection{Physico-Chemical Water and Sediment Core Analyses}

In the water samples $\mathrm{pH}$, conductivity, anions $\mathrm{Cl}^{-}, \mathrm{NO}_{3}{ }^{-}, \mathrm{PO}_{4}{ }^{3-}$, cations $\mathrm{NH}_{4}{ }^{+}, \mathrm{Mg}^{2+}, \mathrm{Ca}^{2+}$, and heavy metals $\mathrm{Cd}, \mathrm{Cu}, \mathrm{Pb}$, and $\mathrm{Zn}$ concentrations were analyzed. $\mathrm{pH}$ and conductivity were measured in situ using a WTW (Multi 340i/SET 2, Wissenschafttlich-Technische Werkstacten 823362 Weiheim, Germany) handheld multimeters. For anion and cation analysis water samples were filtered through a $0.45-\mu \mathrm{m}$ pore-sized syringe filter. They were analyzed within $48 \mathrm{~h}$ from sampling by ion chromatography (DIONEX, IC25 and ICS-1000, Dionex Corporation, Sunnyvale, CA, USA). Concentrations of $\mathrm{Cd}, \mathrm{Pb}, \mathrm{Cu}$, and $\mathrm{Zn}$ in total and dissolved phases (after filtration through $0.45-\mu \mathrm{m}$ filter) were measured by atomic absorption spectroscopy (ASA), using a Varian Spectra AA-20 with a Graphite Furnace (Varian 20, Varian Techtron PTY Limited, Mulgrave, Victoria, Australia). Standard reference materials for water SPS-SW1 Batch 12, National Institute of Standards and Technology (USA), was used to determine the accuracy of metal analyses in the water samples. Water hardness was calculated as a sum of $\mathrm{Ca}$ and $\mathrm{Mg}$ ions. 
Sediment samples for heavy metal analysis were dried at $105^{\circ} \mathrm{C}$ and sieved through a $0.063 \mathrm{~mm}$ sieve. Then they $\left(0.5 \mathrm{~g}\right.$ ) were digested with $10 \mathrm{~cm}^{3}$ of $65 \% \mathrm{HNO}_{3}$ and $2 \mathrm{~cm}^{3}$ of $30 \% \mathrm{H}_{2} \mathrm{O}_{2}$ (both analytical grade) using a microwave digestion technique [14]. The $\mathrm{Cd}, \mathrm{Pb}, \mathrm{Zn}$, and $\mathrm{Cu}$ concentrations were measured with an inductively coupled plasma-mass spectrometer (Perkin Elmer ELAN 6100) in the certified Hydrogeochemical Laboratory (AGH University, Krakow, Poland) according to the standard certified analytical quality control procedure (PN-EN ISO 17294-1:2007).

\subsubsection{Diatoms in Water and Sediment}

In the field, $10 \mathrm{~L}$ of water was collected with a $10-\mu \mathrm{m}$ plankton net. The core samples for diatoms analysis were taken close to the same sites where the plankton was collected. The $1 \mathrm{~cm}^{3}$ samples were taken at $10 \mathrm{~cm}$ intervals immediately after retrieval. The samples for diatom analysis were boiled in concentrated $\mathrm{H}_{2} \mathrm{O}_{2}$, treated with $10 \% \mathrm{HCl}$ and washed several times with distilled water in order to remove organic matter. The cleaned diatom material was air dried on cover slips and mounted in Naphrax Mountant, Brunel Microscopes Ltd. Observations of the diatoms were performed with a Nikon Eclipse 80i microscope equipped with oil immersion and differential interference contrast. The identification of diatoms was based mainly on Krammer and Lange-Bertalot [26-29], and specific taxonomic publications. Taxonomic identifications were made to the lowest possible level. Diatoms collected from the plankton and sediment cores were processed following a procedure-a minimum of 400 valves were counted from every subsample. Only taxa that exceeded $0.2 \%$ of the relative abundance were used for statistical analysis. Diatom data were expressed as relative abundance reflecting changes in the assemblage structure, indicating potential fluctuations in the environment. In order to reconstruct the environmental conditions in plankton and during the deposition of the sediments studied, diatoms were grouped according to their environmental requirements. Here we used a term—sedimentary diatoms—-for all taxa found in the cores.

\subsubsection{Cladocera in Water and Sediment}

Samples for living Cladocera were taken from the central point of each pond. For taxonomic identification and quantitative analyses, samples were collected using a 5-L Ruttner sampler. In the field, $10 \mathrm{~L}$ of water samples (2 replicate, $5 \mathrm{~L}$ samples) were concentrated with a $50-\mu \mathrm{m}$ plankton net. For identification and counting of zooplankton species, five replicate sub-samples were analyzed microscopically $(\times 100$ or $\times 200)$ in the chamber volume of $0.5 \mathrm{~mL}^{-1}$. Taxonomic analyses of Cladocera were conducted using the identification keys [30,31]. The density of individuals were calculated per liter. Subfossil sediment Cladocera were prepared according to Frey [32]. One centimeter cube of fresh homogenized sediment was taken from the particular depths from each core for cladoceran analysis. Laboratory methods were described in a previous publication [25]. Taxa were identified and counted at $200 \times$ or $400 \times$ magnification under a Nikon 50i microscope. All skeletal parts were counted: headshields, shells, postabdomens, postabdominal claws, ephippia, and filtering combs. The most abundant body part for each taxon was chosen to represent the number of individuals. The results of qualitative and quantitative analyses are presented in diagrams, in which an absolute number of specimens was calculated for $1 \mathrm{~cm}^{3}$ sediment volume. Identification of the species was based on Frey [33] and Szeroczyńska and Sarmaja-Korjonen [34].

\subsection{Statistical Analyses}

In order to find the significant differences in the values of studied physicochemical variables in water between UP (CH4-CH5) and DOWN (CH1-CH3) ponds Mann-Whitney test was used. Differences in metal concentrations in the sediments between separate groups (as defined by hierarchical cluster analysis) were evaluated by Mann-Whitney test. To determine the degree of sediment contamination by heavy metals the index of geoaccumulation $\left(\mathrm{I}_{\text {geo }}\right)$ was calculated according to Müller [35] equation: $\mathrm{I}_{\text {geo }}=\log _{2}(\mathrm{Cn} / 1.5 \mathrm{Bn})$, where: $\mathrm{Cn}$ is the mean concentration of an element in the bottom sediment, and $\mathrm{Bn}$ is the geochemical background of the element in the shale [36]. 
According to values of the IgeoMüller [35] we distinguished seven classes of sediment contamination; Class 0 , $\mathrm{I}_{\text {geo }} \leq 0$, uncontaminated; Class $1,0<\mathrm{I}_{\text {geo }} \leq 1$, uncontaminated to moderately contaminated; Class 2, $1<\mathrm{I}_{\text {geo }} \leq 2$, moderately contaminated; Class 3, $2<\mathrm{I}_{\text {geo }} \leq 3$, moderately to heavily contaminated; Class 4, $3<\mathrm{I}_{\text {geo }} \leq 4$, heavily contaminated; Class $5,4<\mathrm{I}_{\text {geo }} \leq 5$, heavily to extremely contaminated; Class 6, $\mathrm{I}_{\text {geo }}>5$, extremely contaminated. Shannon's diversity index was applied in order to evaluate the diversity of Cladocera and Bacillariophyta (diatoms) (MultiVariate Statistical Package (MVSP) 3.1 program, Kovach Computing Services).

We used Spearman's correlation coefficient to investigate the relationship between cladocerans and diatoms occurrence and the content of heavy metals in the sediments and the physico-chemical characteristics of the waters (Statistica 13 program).

Cladocera and diatom communities were classified based on their similarities using the hierarchical clustering method (UPGMA). The clustering classification was obtained using the MVSP 3.1 program.

The significance of the differences between ponds created during mine exploitation (DOWN) and those created after the mine was closed (UP) and the density of diatoms and cladocerans were evaluated using Mann-Whitney U test (Statistica version 13.1, Dell version).

Canonical correspondence analysis (CCA) was used to analyze species and environmental data. We performed DCA analysis (detrended correspondence analysis) based on the length of the gradient expressed in standard deviation (SD) units. For DCA and CCA analysis, the data was log-transformed $\ln (x+1)$ and centered. In the CCA analysis a forward selection was used to reduce the set of environmental variables. Analysis was performed on cladocerans and diatoms data and sediments samples to identify the changes in the water bodies and to show the relationships between the environmental variables and the distribution of studied organisms. The statistical significance, as well as the statistical significance of canonical axes, was accessed using the Monte Carlo permutation test for 499 repetitions (CANOCO for Windows 4.5 program).

\section{Results}

\subsection{Physico-Chemical Variates in Waters of Subsidence Ponds}

The water of ponds was from circumneutral to slightly alkaline $\mathrm{pH}$ (6.7-7.9). Conductivity ranged between 412 and $892 \mu \mathrm{S} \mathrm{cm}^{-1}$, contents of major anions $\left(\mathrm{mg} / \mathrm{dm}^{3}\right)$ varied: $\mathrm{Cl}^{-}$25.1-82.8, $\mathrm{SO}_{4}{ }^{2-} 25.2-165.7$, $\mathrm{HCO}_{3}{ }^{-}$104-265, cations $\mathrm{Mg}^{2+} 10.8-26.5, \mathrm{Ca}^{2+} 38.3-86.1$, total hardness $2.8-6.3 \mathrm{mval} / \mathrm{dm}^{3}$, alkalinity $1.7-4.3 \mathrm{mval} / \mathrm{dm}^{3}, \mathrm{NO}_{3}{ }^{-}$nd (not detected)-21.2 and $\mathrm{PO}_{4}{ }^{3-}$ 0.10-1.52. The result of Mann-Whitney test indicated significantly higher values of conductivity, $\mathrm{pH}$, concentrations of ions $\mathrm{Cl}^{-}, \mathrm{SO}_{4}{ }^{2-}$, $\mathrm{Mg}^{2+}, \mathrm{NO}_{3}{ }^{-}, \mathrm{PO}_{4}{ }^{3-}$ in the UP pond when compared to those at the DOWN ponds (Tables 1 and 2). Some parameters show differences between the sites at the DOWN ponds. The lowest medians of conductivity, ions $\mathrm{SO}_{4}{ }^{2-}, \mathrm{Cl}^{-}$, and $\mathrm{PO}_{4}{ }^{3-}$ were found at site $\mathrm{CH} 3$ (Table 1). The highest variability of concentrations of the major ions (with the exception of hydrocarbonates), nutrients, and total hardness was found in the UP pond (site CH5) (Table 1).

Total heavy metal concentrations in water varied in following ranges (in $\mu \mathrm{g} / \mathrm{dm}^{3}$ ): Cd nd-4.6, $\mathrm{Pb}$ 1.0-20.3, Cu nd-5.0, and Zn 20.0-91.3, while metals in dissolved phase varied: $\mathrm{Cd}$ nd-0.53, $\mathrm{Pb} 0.1-7.3$, $\mathrm{Zn}$ nd-47.1. In the studied waters the concentrations of $\mathrm{Cd}$ total was usually $<0.6 \mu \mathrm{g} / \mathrm{dm}^{3}, \mathrm{~Pb}$ total $<5.5 \mu \mathrm{g} / \mathrm{dm}^{3}$, Zn total $<45 \mu \mathrm{g} / \mathrm{dm}^{3}(70 \%, 70 \%$, and $60 \%$ of cases, respectively), while Cd dissolved $<0.13 \mu \mathrm{g} / \mathrm{dm}^{3}, \mathrm{~Pb}$ dissolved $<2 \mu \mathrm{g} / \mathrm{dm}^{3}$, and $\mathrm{Zn}$ dissolved $<30 \mu \mathrm{g} / \mathrm{dm}^{3}$ (and $65 \%, 75 \%$, and $80 \%$ of cases, respectively). The concentrations of $\mathrm{Zn}$ total were significantly higher in water of the UP pond than those in DOWN ponds (Table 2). The highest metal concentrations in water appeared in different seasons and sites. Maximum concentrations of $\mathrm{Cd}$ total and dissolved and $\mathrm{Pb}$ total and dissolved in all waters were found in August (with the exception of $\mathrm{Pb}$ total in the pond $\mathrm{CH} 1$ and $\mathrm{Pb}$ dissolved in pond $\mathrm{CH} 4$ ). Then, the concentrations of $\mathrm{Pb}$ (total and dissolved) were ca. 2-3 times higher in ponds $\mathrm{CH} 2$ and $\mathrm{CH} 3$ than in $\mathrm{CH} 4$ and $\mathrm{CH} 5$. The highest concentrations of total $\mathrm{Cd}$ and $\mathrm{Zn}$ were found at site $\mathrm{CH} 5, \mathrm{~Pb}$ at site $\mathrm{CH} 2$, while $\mathrm{Cu}$ at site $\mathrm{CH} 4$ (Table 1). 
Table 1. Physico-chemical parameters (median, range) of the waters of the subsidence ponds.

\begin{tabular}{|c|c|c|c|c|c|c|c|c|c|c|}
\hline \multirow{3}{*}{ Parameter } & \multicolumn{10}{|c|}{ Sites } \\
\hline & \multicolumn{2}{|c|}{$\mathrm{CH} 1$} & \multicolumn{2}{|c|}{$\mathrm{CH} 2$} & \multicolumn{2}{|c|}{$\mathrm{CH} 3$} & \multicolumn{2}{|c|}{$\mathrm{CH} 4$} & \multicolumn{2}{|c|}{ CH5 } \\
\hline & Median & Range & Median & Range & Median & Range & Median & Range & Median & Range \\
\hline $\mathrm{pH}$ & 6.8 & $6.7-7.1$ & 6.8 & $6.7-7.5$ & 7.1 & $7.0-7.4$ & 7.3 & $7.0-7.5$ & 7.5 & $7.1-7.9$ \\
\hline Conductivity $(\mu \mathrm{S} / \mathrm{cm})$ & 502 & $464-535$ & 515 & $434-588$ & 460 & $412-470$ & 838 & $825-862$ & 848 & $773-892$ \\
\hline $\mathrm{Cl}^{-}\left(\mathrm{mg} / \mathrm{dm}^{3}\right)$ & 38.2 & $33.3-42.6$ & 40.5 & $29.8-46.0$ & 30.2 & $25.1-32.5$ & 70.1 & $38.1-76.3$ & 65.3 & $39.4-82.8$ \\
\hline $\mathrm{SO}_{4}{ }^{2-}\left(\mathrm{mg} / \mathrm{dm}^{3}\right)$ & 61.0 & $53.6-82.4$ & 64.0 & $53.3-81.6$ & 42.7 & $25.2-50.3$ & 150.7 & $80.4-156.1$ & 151.8 & $70.8-165.7$ \\
\hline $\mathrm{HCO}_{3}{ }^{-}\left(\mathrm{mg} / \mathrm{dm}^{3}\right)$ & 175 & $167-217$ & 174 & $147-241$ & 180 & $176-200$ & 204 & $104-265$ & 202 & $112-236$ \\
\hline $\mathrm{Ca}^{2+}\left(\mathrm{mg} / \mathrm{dm}^{3}\right)$ & 53.3 & $48.5-64.3$ & 52.6 & $45.9-70.0$ & 56.2 & $51.4-61.8$ & 80.8 & $39.4-86.1$ & 83.5 & $38.3-85.6$ \\
\hline $\mathrm{Mg}^{2+}\left(\mathrm{mg} / \mathrm{dm}^{3}\right)$ & 15.0 & $13.5-17.6$ & 13.1 & $11.6-17.7$ & 13.8 & $12.2-14.2$ & 22.5 & $12.0-24.4$ & 23.6 & $10.8-26.5$ \\
\hline $\mathrm{NO}_{3}{ }^{-}\left(\mathrm{mg} / \mathrm{dm}^{3}\right)$ & 9.4 & $5.1-15.6$ & 0.6 & $0.2-2.2$ & 1.8 & $0.7-4.3$ & 6.7 & $3.8-9.4$ & 10.9 & $6.8-21.2$ \\
\hline $\mathrm{PO}_{4}{ }^{3-}\left(\mathrm{mg} / \mathrm{dm}^{3}\right)$ & 0.14 & $0.10-0.18$ & 0.29 & $0.12-1.28$ & 0.29 & $0.06-0.71$ & 0.60 & $0.27-1.10$ & 0.49 & $0.22-1.52$ \\
\hline Total hardness $\left(\mathrm{mval} / \mathrm{dm}^{3}\right)$ & 3.8 & $3.6-4.7$ & 3.7 & $3.3-4.9$ & 3.9 & $3.7-4.2$ & 5.9 & $3.0-6.2$ & 6.2 & $2.8-6.3$ \\
\hline Alkalinity $\left(\mathrm{mval} / \mathrm{dm}^{3}\right)$ & 2.9 & $2.7-3.6$ & 2.9 & $2.4-4.0$ & 3.0 & $2.9-3.3$ & 3.3 & $1.7-4.3$ & 3.3 & $1.8-3.9$ \\
\hline Cd total $\left(\mu \mathrm{g} / \mathrm{dm}^{3}\right)$ & 0.60 & $0.15-0.87$ & 1.00 & nd-1.80 & 0.33 & nd-0.51 & 0.38 & $0.16-1.00$ & 0.56 & $0.48-4.60$ \\
\hline Cd dissolved $\left(\mu \mathrm{g} / \mathrm{dm}^{3}\right)$ & 0.09 & $0.07-0.53$ & 0.18 & nd-0.31 & 0.30 & nd-0.39 & 0.06 & $0.06-0.39$ & 0.22 & $0.06-0.47$ \\
\hline $\mathrm{Pb}$ total $\left(\mu \mathrm{g} / \mathrm{dm}^{3}\right)$ & 2.4 & $2.1-2.6$ & 4.9 & $1.2-20.3$ & 4.6 & $3.0-12.9$ & 1.3 & $1.0-6.9$ & 5.3 & $2.7-7.7$ \\
\hline $\mathrm{Pb}$ dissolved $\left(\mu \mathrm{g} / \mathrm{dm}^{3}\right)$ & 1.5 & $0.9-2.4$ & 0.7 & $0.2-5.0$ & 1.7 & $1.6-7.3$ & 1.0 & $0.1-2.3$ & 1.2 & $0.5-3.3$ \\
\hline $\mathrm{Cu}$ total $\left(\mu \mathrm{g} / \mathrm{dm}^{3}\right)$ & 2.5 & $2.0-3.0$ & 1.5 & $1.0-5.0$ & 2.00 & nd-3.0 & 2.0 & nd-6.0 & 4.0 & nd-4.0 \\
\hline $\mathrm{Zn}$ total $\left(\mu \mathrm{g} / \mathrm{dm}^{3}\right)$ & 36.0 & $29.7-37.6$ & 28.3 & $22.1-47.6$ & 35.9 & $20.0-68.1$ & 47.7 & $27.2-79.0$ & 75.6 & $40.8-91.3$ \\
\hline Zn dissolved $\left(\mu \mathrm{g} / \mathrm{dm}^{3}\right)$ & 24.3 & $17.6-28.4$ & 19.3 & nd-23.6 & 21.6 & nd-24.3 & 23.6 & $21.5-38.1$ & 39.5 & $27.0-47.1$ \\
\hline
\end{tabular}


Table 2. Significant differences in the values of studied physico-chemical parameters in water between the UP (CH4, CH5) and DOWN (CH1-CH3) ponds (Mann-Whitney test). Only significant differences are given.

\begin{tabular}{ccc}
\hline Parameter & $\mathrm{Z}$ & $p$ \\
\hline $\mathrm{pH}$ & 2.546 & 0.010 \\
Conductivity & 3.665 & 0.000 \\
$\mathrm{Cl}^{-}$ & 3.047 & 0.002 \\
$\mathrm{SO}_{4}{ }^{2-}$ & 3.356 & 0.000 \\
$\mathrm{Mg}^{2+}$ & 1.967 & 0.049 \\
$\mathrm{NO}_{3}{ }^{-}$ & 2.198 & 0.027 \\
$\mathrm{PO}_{4}{ }^{3-}$ & 2.198 & 0.027 \\
$\mathrm{Zn}$ total & 2.507 & 0.012 \\
\hline
\end{tabular}

\subsection{Heavy Metals in Sediments of Subsidence Ponds}

Metal concentrations in the sediment cores significantly varied (in $\mu \mathrm{g} / \mathrm{g}$ ): Cd 6.1-612.0, $\mathrm{Pb}$ 302.6-10,223, Cu 21.4-397, and Zn 506.7-23,081 (Figure 2). Metal concentrations in the cores RVI, RVII, and RXII (0-10 cm strata) were from a few to several dozen times higher in the DOWN ponds than those in cores RI and RIV from the UP pond (Figure 2). Metal concentrations in the lower and/or middle strata (10-20 and 20-30 cm) of core RXII were similar to those in the UP pond (Figure 2).

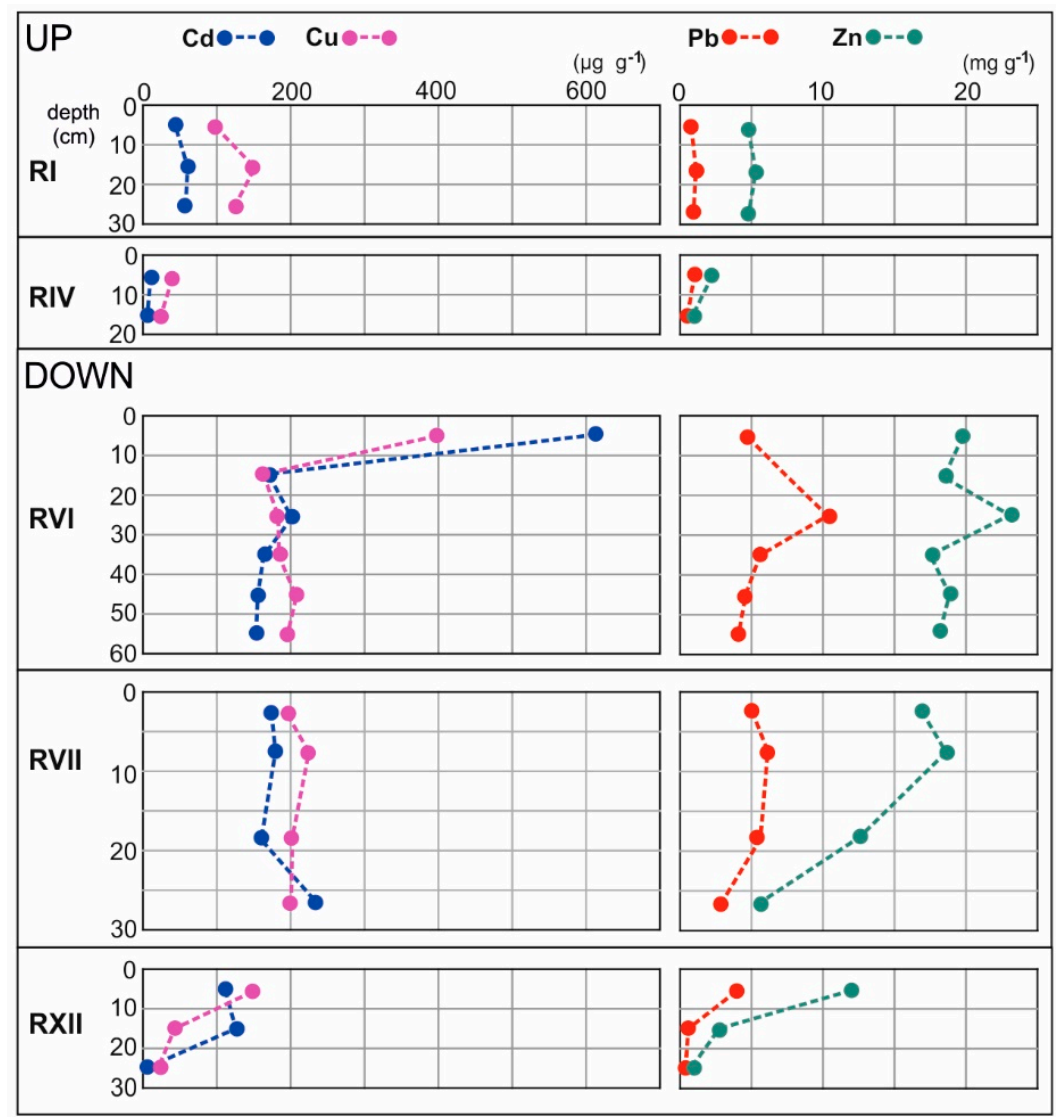

Figure 2. Heavy metal concentrations in the sediment cores in subsidence ponds (UP: Subsidence pond formed after the closure of the mine; cores: RI, RIV; DOWN: Subsidence ponds formed during peak of exploitation; cores: RVI, RVII, RXII).

According to the geoaccumulation index, the 0-10 cm strata of sediment cores RVI, RVII, RXII, and of core $\mathrm{RI}$ (with the exception of $\mathrm{Pb}$ were extremely contaminated by $\mathrm{Zn}, \mathrm{Cd}$, and $\mathrm{Pb}\left(\mathrm{I}_{\text {geo }}>5\right.$, class 6) (Table 3). Additionally, they were extremely contaminated by $\mathrm{Cd}$ in the core RXII at the depth 
10-20 cm. Other sediment strata in cores RXII, RVII, and RIV were moderately to heavily contaminated by $\mathrm{Zn}$ (classes II-V) and heavily contaminated by $\mathrm{Cd}$ and $\mathrm{Pb}$ (classes IV-V). Sediments were usually uncontaminated or weakly contaminated by $\mathrm{Cu}$ (classes $0-\mathrm{II})$.

\subsection{Diatom Analysis in Water and Sediments in Subsidence Ponds}

Planktonic diatoms were represented by 51 taxa belonging to 26 genera. Gomphonema (9), Nitzschia (9), Fragilaria (5) were the most diverse genera. The most abundant taxa in ponds existing during the mine operation (DOWN) were: Achnanthidium minutissimum (CH3), Staurosira binodis (CH2), Lemnicola hungarica $(\mathrm{CH} 2)$, Nitzschia supralitorea $(\mathrm{CH} 1, \mathrm{CH} 3)$, and Sellaphora nigri $(\mathrm{CH} 2)$. In the pond that emerged after the mining cessation (UP) the most common diatoms were Achnanthidium minutissimum (CH4), Gomphonema parvulum (CH5), Hippodonta capitata (CH4), and Planothidium frequentissimum (CH4). They reached at least more than $10 \%$ of relative abundance in at least one sample.

Diatoms in the sediment were much more diverse in number of taxa. Totally, 230 taxa (66 genera) were found. The most abundant genera belonged to: Nitzschia (29), Gomphonema (16), and Fragilaria (14), but they were much more diverse in number of species than plankton. Among the most abundant taxa in the DOWN pond have been found: Achnanthidium minutissimum (RVI, RVII), Meridion circulare var. circulare (RVI, RVII), Sellaphora nigri (RVI), Staurosira venter (RXII), Surirella brebisonii var. kuetzingii (RVII), whereas in the pond that emerged after mine closure (UP) Gomphonema utae (RIV), Planothidium lanceolatum (RIV), Staurosira venter (RI) occurred in the largest amounts. Staurosira venter in core RXII showed over $90 \%$ dominance.

\subsection{Cladocera Analysis in Water and Sediments in Subsidence Ponds}

Planktonic Cladocera were represented by 13 taxa belonging to five families (Bosminidae, Chydoridae, Daphniidae, Eurycercidae, Polyphemidae). Daphniidae (5 taxa: Ceriodaphnia quadrangula, Daphnia pulex, Moina micrura, Scapholeberis mucronata, Simocephalus vetulus) and Chydoridae (5 taxa: Coronatella rectangula, Alonella exigua, A. nana, Chydorus sphaericus, Pleuroxus truncatus) were the most diverse, whereas the other families were represented by only one taxon. The highest density of total Cladocera was noted in $\mathrm{CH} 1$ pond while Daphnia pulex had the highest density during the summer in CH3 (121 ind./ $\left./ \mathrm{dm}^{3}\right), \mathrm{CH} 5$ (117 ind./ $\left.\mathrm{dm}^{3}\right), \mathrm{CH} 1$ (267 ind./ $\left.\mathrm{dm}^{3}\right)$ ponds. In the UP pond, 8 taxa were found, against 12 taxa in the DOWN ponds. The number of cladoceran taxa in each plankton sampling point ranged from 4 to 9 (Table 3 ).

Table 3. Number of taxa and density of Cladocera in water and sediment of subsidence ponds.

\begin{tabular}{|c|c|c|c|c|c|c|}
\hline \multirow[b]{2}{*}{ Title } & \multicolumn{3}{|c|}{ Plankton } & \multicolumn{3}{|c|}{ Sediment } \\
\hline & $\begin{array}{l}\text { Sampling } \\
\text { Point }\end{array}$ & $\begin{array}{c}\text { Number } \\
\text { of Taxa }\end{array}$ & 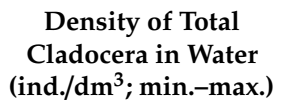 & Core & $\begin{array}{c}\text { Number of } \\
\text { Taxa }\end{array}$ & $\begin{array}{l}\text { Range (min.-max.) of } \\
\text { Total Cladocera (ind. } \\
1 \mathrm{~cm}^{3} \text { ) in Sediments }\end{array}$ \\
\hline \multirow[b]{2}{*}{ UP } & $\mathrm{CH} 4$ & 7 & 2-99 & RIV & 7 & $4-20$ \\
\hline & $\mathrm{CH} 5$ & 4 & $1-132$ & RI & 5 & $1-6$ \\
\hline \multirow{3}{*}{ DOWN } & $\mathrm{CH} 1$ & 8 & $2-278$ & RVI & 3 & $3-8$ \\
\hline & $\mathrm{CH} 2$ & 9 & $7-47$ & RXII & 13 & 24-111 \\
\hline & $\mathrm{CH} 3$ & 6 & 2-131 & RVII & 2 & $1-6$ \\
\hline
\end{tabular}

Cladocera remains in the sediments of the subsidence ponds were represented by 15 taxa belonging to three families (Bosminidae, Chydoridae, Daphniidae). Chydoridae was the most diverse family (11 taxa), other families had fewer taxa (Bosminidae-1; Daphniidae-3). The number of cladoceran taxa per sediment core ranged from 2 to 13 (Figure 3, Table 3). The highest density of total Cladocera in subsidence ponds was noted in the core RXII (111 ind./ $\left.\mathrm{cm}^{3}\right)$ (DOWN). Alona sp. (33 ind./ $\left./ \mathrm{cm}^{3}\right)$ and Chydorus sphaericus $\left(21\right.$ ind. $/ \mathrm{cm}^{3}$ ) had the highest density in this core. In subsidence ponds (in plankton and sediment) we found 8 taxa in the UP pond characterized by through-flow of river water and 14 taxa in DOWN ponds characterized by stagnant water conditions and littoral zone overgrown 
with macrophytes. In all ponds we found taxa belonging to five genera: Acroperus, Alona, Bosmina, Coronatella, Chydorus, and Daphnia.

The pond (CH2; RXII; Table 3) had the highest diversity of Cladocera taxa in comparison with the other DOWN reservoirs. Total density of Cladocera remains in sediments (ind./ $\mathrm{cm}^{3}$ ) varied from 1 in UP pond (RI) to over 100 individuals in core XII in DOWN ponds (Table 3). In the UP pond Cladocera assemblage was rather poor and its density was not higher than 20 ind. $/ \mathrm{cm}^{3}$. Chydorus sphaericus was dominant, present in all studied ponds. Chydorus sphaericus is known in pelagic and littoral zones, and its high density is characteristic for eutrophic and polluted water. The highest density of this species was observed in the core RXII (21 ind./ $\left.\mathrm{cm}^{3}\right)$, in the pond of mining area (DOWN) whereas, a much smaller density, below $10 \mathrm{ind} . / \mathrm{cm}^{3}$ was observed in cores of the pond formed after the mining period (UP) (Figure 3). 


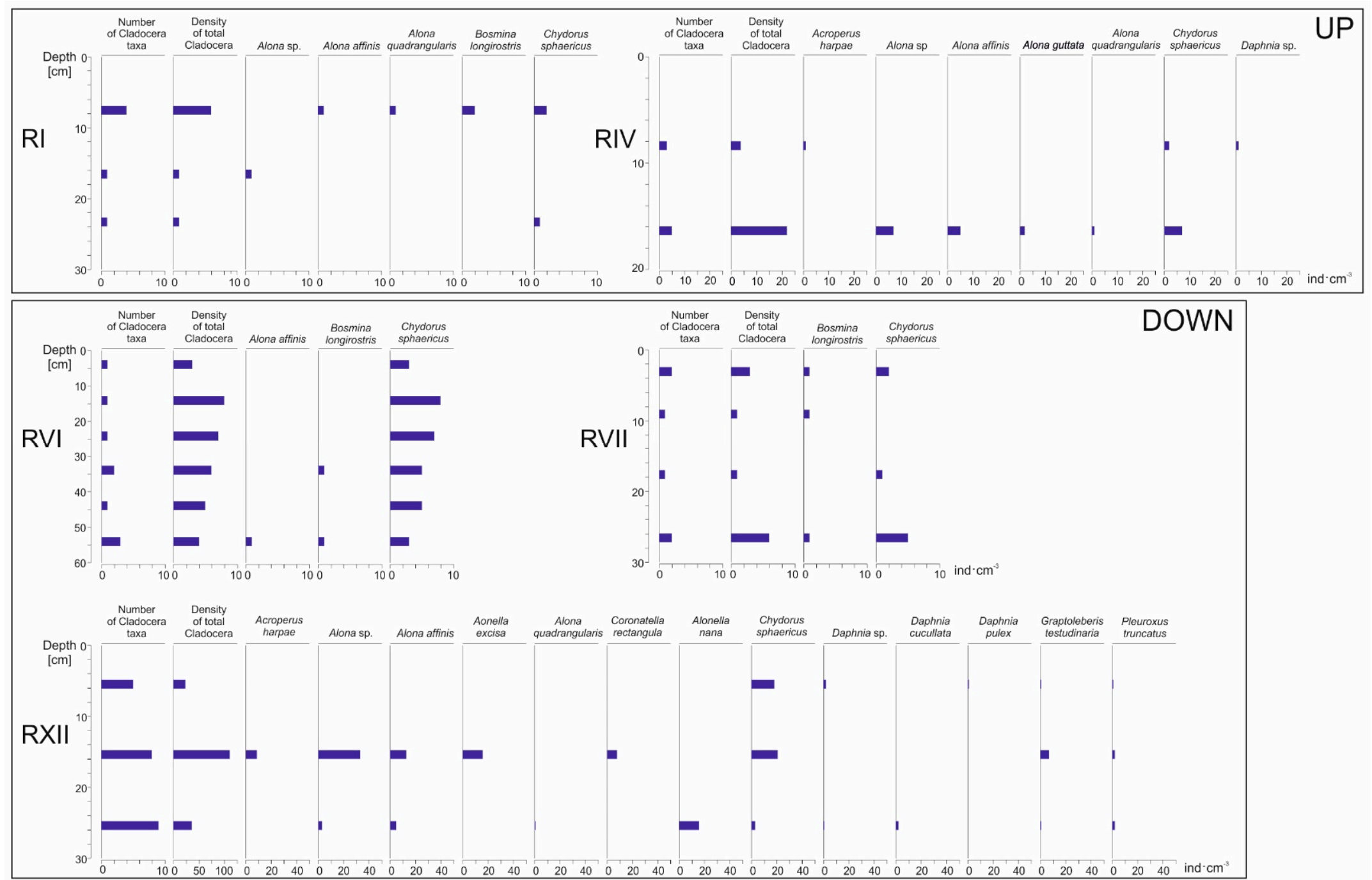

Figure 3. Density of Cladocera taxa in sediment cores (ind. $/ \mathrm{cm}^{3}$ ) from subsidence pond created after mine was closed (UP) and ponds existed during mine exploitation (DOWN). 


\subsection{Relationship between Diatoms, Cladocera, and Environmental Variables in Subsidence Ponds}

The highest Shannon $\left(\mathrm{H}^{\prime}\right)$ diversity rates (up to 4) occurred for plankton and for diatoms of six sediment samples from UP and DOWN ponds. Values of the index for Cladocera community were different from those obtained for diatoms. Moreover, the high $\mathrm{H}^{\prime}$ diversity rates of Cladocera communities were observed in the two sediment cores (up to $<1$ ) from water bodies which were formed after mining (UP), as well as in a one plankton sample and in a one sediment core from the DOWN pond (Table 4).

Table 4. Shannon $\left(\mathrm{H}^{\prime}\right)$ diversity index value in investigated plankton samples and sediment cores. (UP-subsidence pond formed after mine was closed; DOWN-subsidence ponds formed during the peak of $\mathrm{Zn}$ and $\mathrm{Pb}$ ore exploitation).

\begin{tabular}{ccccccccc}
\hline \multirow{2}{*}{ Title } & \multicolumn{3}{c}{ UP } & \multicolumn{4}{c}{ DOWN } \\
\cline { 2 - 9 } & \multirow{2}{*}{ Plankton } & $\begin{array}{l}\text { Index } \\
\text { Value }\end{array}$ & Core & $\begin{array}{l}\text { Index } \\
\text { Value }\end{array}$ & Plankton & $\begin{array}{l}\text { Index } \\
\text { Value }\end{array}$ & Core & $\begin{array}{c}\text { Index } \\
\text { Value }\end{array}$ \\
\hline \multirow{3}{*}{ Diatoms } & CH4 & 2.945 & RIV & 3.671 & CH1 & 3.105 & RVI & 3.426 \\
& CH5 & 3.304 & RI & 3.296 & CH2 & 2.483 & RXII & 2.423 \\
& & & & & CH3 & 2.746 & RVII & 3.698 \\
\hline \multirow{3}{*}{ Cladocera } & CH4 & 0.782 & RIV & 1.611 & CH1 & 0.740 & RVI & 0.356 \\
& CH5 & 0.558 & RI & 1.520 & CH2 & 1.382 & RXII & 2.125 \\
& & & & & CH3 & 0.498 & RVII & 0.591 \\
\hline
\end{tabular}

The analysis of similarities of the plankton community (diatoms and cladocerans) ordered communities without distinguishing groups with respect to their similarity. This was caused by the different dominance of the identified species structure of diatoms and cladocerans at the sampling sites. The three closely situated DOWN ponds were characterized by stagnant water and were formed during the mine exploitation (D-CH1, D-CH3, D-CH2). The furthest two sampling sites were situated in a pond formed after the mine was closed, and the pond was characterized by a flow-through of water (U-CH4, U-CH5) (Figure 4).

UPGMA

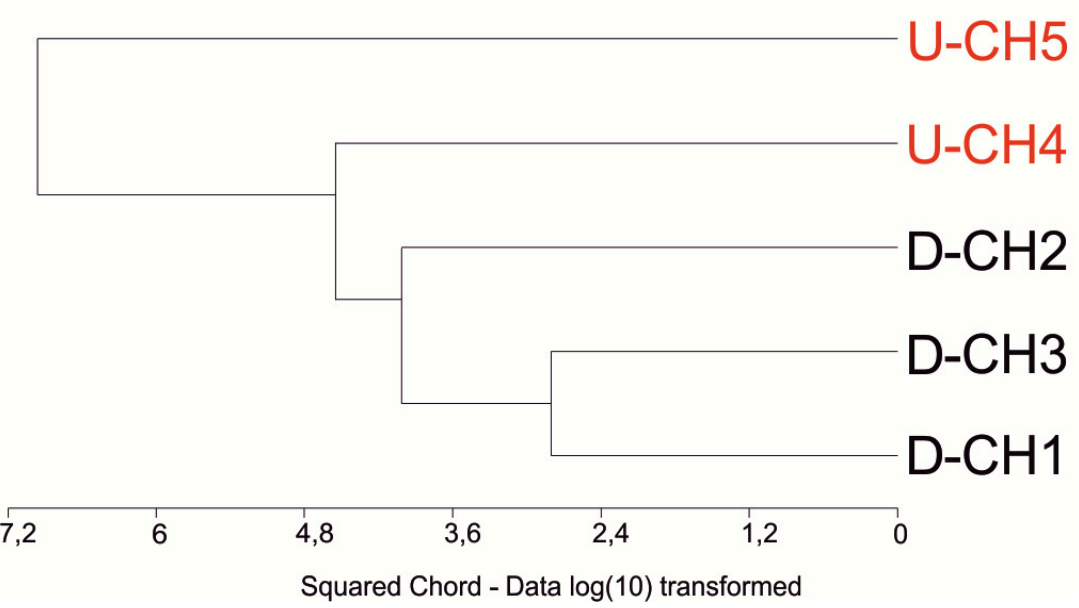

Figure 4. Dendrogram of similarities constructed for diatom and Cladocera in plankton samples from pond, created after mine was closed (UP) (U-CH5, U-CH4) and ponds existed during mine exploitation (DOWN) (D-CH3, D-CH2, D-CH1).

There were statistically significant correlations between the abundance of particular species of diatoms and cladocerans and physico-chemical data (also heavy metals) of water as well as the 
abundance of diatoms and cladocerans and heavy metal concentrations in the sediment cores of UP and DOWN ponds (Tables 5-8).

In the UP pond we did not find a significant correlation between heavy metals in water and planktonic diatoms. However, the highest and significant Spearman's rank correlation were found for Aulacoseira ambigua, Pseudostaurosira brevistriata, and Staurosirella pinnata (all for Zn dissolved), Melosira varians (negative correlation), Navicula cryptocephala (both for $\mathrm{Pb}$ dissolved) and significant negative correlation for Cyclotella meneghiniana (Cd dissolved) (Table 5A). In the sediment from the UP pond, significant positive correlations (Spearman's rank order) were found between Aulacoseira ambigua and $\mathrm{Cu}$ and between Encyonema ventricosum and $\mathrm{Zn}$ and $\mathrm{Cd}$. Other species of diatoms negatively correlated with the heavy metal content in sediment (Table 6A).

In the DOWN ponds (existing during the mine operation) the highest Spearman's rank order correlation (significant) were found for ten planktonic diatom species and metal content in water, among which the highest were for: Achnanthidium minutissimum $(\mathrm{Pb})$, Cocconeis placentula var. placentula $(\mathrm{Pb})$, Fragilaria cf. famelica $(\mathrm{Cd})$, and Staurosira venter $(\mathrm{Cd}, \mathrm{Zn})$. Other diatoms were negatively correlated with heavy metal content (Melosira varians, Nitzchia archibaldii, N. linearis, N. palea var. debilis, Sellaphora saugerresii, Thalasiosira pseudonana) (Table 7A).

In the sediment samples of DOWN ponds, such diatoms as Achnanthidium minutissimum $(\mathrm{Cd}, \mathrm{Cu})$, Asterionella formosa $(\mathrm{Zn})$, Aulacoseira granulata $(\mathrm{Cd})$, Encyonopsis cesatii $(\mathrm{Pb})$, Fragilaria cf. gracilis $(\mathrm{Cd}$, $\mathrm{Zn}, \mathrm{Pb})$, Meridion circulare var. circulare $(\mathrm{Zn}, \mathrm{Cu}, \mathrm{Pb})$, Navicula veneta $(\mathrm{Cu})$, Nitzchia archibaldii $(\mathrm{Cd}, \mathrm{Zn}$, $\mathrm{Cu}, \mathrm{Pb}), N$. capitellata $(\mathrm{Zn}, \mathrm{Cu}, \mathrm{Pb}), N$. gracilis $(\mathrm{Cd}, \mathrm{Zn}, \mathrm{Pb}), N$. palea var. debilis $(\mathrm{Zn}), N$. subacicularis $(\mathrm{Pb})$, Planothidium lanceolatum $(\mathrm{Cd}, \mathrm{Zn}, \mathrm{Pb})$, Sellaphora nigri $(\mathrm{Cd}, \mathrm{Zn}, \mathrm{Pb}, \mathrm{Cu})$, Surirella angusta $(\mathrm{Pb})$, S. brebisonii var. kuetzingii $(\mathrm{Cd}, \mathrm{Zn}, \mathrm{Pb}, \mathrm{Cu})$, and Ulnaria ulna $(\mathrm{Zn}, \mathrm{Pb})$ significantly correlated with the heavy metals. Among 25 significantly correlated species Nitzchia archibaldii, Sellaphora nigri, and Surirella brebisonii var. kuetzingii have highly significant positive correlation values with all analyzed heavy metals (Table 8A). The highest correlation values with Pb concentrations were obtained for Encyonopsis cesatii (0.793), Sellaphora nigri, and Surirella brebisonii var. kuetzingii (0.756 and 0.839 respectively). The remaining diatoms were negatively correlated with the heavy metals content (Table 8A). 
Table 5. Spearman's rank order correlation for planktonic diatoms (A) and cladocerans (B) from pond created after mine was closed (UP).

\begin{tabular}{|c|c|c|c|c|c|c|c|c|c|c|c|}
\hline \multicolumn{12}{|c|}{ (A) Diatoms } \\
\hline Species & Conductivity & $\mathrm{pH}$ & $\begin{array}{c}\text { Cd } \\
\text { Dissolved }\end{array}$ & $\begin{array}{c}\mathrm{Pb} \\
\text { Dissolved }\end{array}$ & $\begin{array}{c}\mathrm{Zn} \\
\text { Dissolved }\end{array}$ & $\begin{array}{c}\text { Aulacoseira } \\
\text { ambigua }\end{array}$ & $\begin{array}{c}\text { Pseudostaurosira } \\
\text { brevistriata }\end{array}$ & $\begin{array}{l}\text { Nitzschia palea } \\
\text { var. palea }\end{array}$ & & & \\
\hline Aulacoseira ambigua & 0.814 & & & & 0.731 & & & & & & \\
\hline Cyclotella meneghiniana & & & -0.812 & & & & & & & & \\
\hline Melosira varians & 0.774 & & & -0.736 & & 0.778 & & & & & \\
\hline Navicula cryptocephala & & & & 0.733 & & & & & & & \\
\hline Nitzschia capitellata & & 0.766 & & & & & & & & & \\
\hline Nitzschia palea var. palea & 0.764 & & & & & & 0.719 & & & & \\
\hline Nitzschia supralitorea & & -0.764 & & & & & & & & & \\
\hline $\begin{array}{l}\text { Pseudostaurosira } \\
\text { brevistriata }\end{array}$ & & & & & 0.736 & 0.768 & & & & & \\
\hline $\begin{array}{l}\text { Staurosira construens } \\
\text { Staurosirella pinnata }\end{array}$ & 0.764 & & & & 0.896 & 0.768 & 0.839 & 0.839 & & & \\
\hline \multicolumn{12}{|c|}{ (B) Cladocerans } \\
\hline Species & $\mathrm{SO}_{4}{ }^{2-}$ & $\mathrm{NO}_{3}{ }^{-}$ & $\mathrm{PO}_{4}{ }^{3-}$ & $\begin{array}{c}\text { Craticula } \\
\text { buderi }\end{array}$ & $\begin{array}{l}\text { Craticula } \\
\text { cuspidata }\end{array}$ & $\begin{array}{c}\text { Fragilaria } \\
\text { bidens }\end{array}$ & $\begin{array}{l}\text { Gomphonema } \\
\text { parvulum }\end{array}$ & $\begin{array}{c}\text { Halamphora } \\
\text { veneta }\end{array}$ & $\begin{array}{c}\text { Navicula } \\
\text { cryptocephala }\end{array}$ & $\begin{array}{c}\text { Sellaphora } \\
\text { nigri }\end{array}$ & $\begin{array}{l}\text { Sellaphora } \\
\text { saugerresii }\end{array}$ \\
\hline Bosmina longirostris & & & & & & 0.756 & & & & & \\
\hline Ceriodaphnia quadrangula & & & & & & & & & 0.756 & & \\
\hline Chydorus sphaericus & & & & 0.814 & & & & 0.750 & & 0.768 & 0.765 \\
\hline Daphnia pulex & & 0.826 & 0.802 & & & & & & & & \\
\hline Moina micrura & 0.764 & 0.764 & & & 0.751 & & 0.733 & & & & \\
\hline Pleuroxus truncatus & & & & & & & & & 0.756 & & \\
\hline Scapholeberis mucronata & & & & & & & & & 0.750 & & \\
\hline
\end{tabular}


Table 6. Spearman's rank order correlation for diatoms (A) and cladocerans (B) from sediment core of subsidence pond (UP).

\begin{tabular}{|c|c|c|c|c|c|c|c|c|c|c|c|}
\hline \multicolumn{12}{|c|}{ (A) Diatoms } \\
\hline Species & Zn & Cd & $\mathrm{Pb}$ & $\mathrm{Cu}$ & $\begin{array}{c}\text { Caloneis } \\
\text { lancettula }\end{array}$ & $\begin{array}{l}\text { Diploneis } \\
\text { fontanella }\end{array}$ & $\begin{array}{l}\text { Encyonema } \\
\text { perpusillum }\end{array}$ & $\begin{array}{l}\text { Gomphonema } \\
\text { utae }\end{array}$ & $\begin{array}{l}\text { Staurosirella } \\
\text { leptostauron }\end{array}$ & $\begin{array}{l}\text { Surirella brebisonii } \\
\text { var. kuetzingii }\end{array}$ & $\begin{array}{l}\text { Tabellaria } \\
\text { flocullosa }\end{array}$ \\
\hline Aulacoseira ambigua & & & & 0.845 & & & & & & & \\
\hline Caloneis lancettula & -0.828 & -0.828 & & -0.828 & & & & & & & \\
\hline Diploneis fontanella & -0.820 & -0.820 & & & 0.880 & & & & & & \\
\hline Encyonema perpusillum & -0.828 & -0.828 & & -0.828 & & 0.880 & & & & & \\
\hline Encyonema ventricosum & 0.820 & 0.820 & & & & -0.871 & & & & & \\
\hline Gomphonema utae & & & & -0.812 & 0.840 & & 0.840 & & & & \\
\hline Navicula radiosa & -0.845 & -0.845 & & -0.845 & 0.980 & 0.898 & 0.980 & 0.857 & & & \\
\hline Nitzschia acidoclinata & -0.845 & -0.845 & & -0.845 & 0.980 & 0.898 & 0.980 & 0.857 & & & \\
\hline Pinnularia borealis & -0.845 & -0.845 & & -0.845 & 0.980 & 0.898 & 0.980 & 0.857 & & & \\
\hline Punctastriata sp. & -0.845 & -0.845 & & -0.845 & 0.980 & 0.898 & 0.980 & 0.857 & & & \\
\hline Staurosirella leptostauron & & & -0.845 & & & & & & & & \\
\hline \multicolumn{12}{|c|}{ (B) Cladocerans } \\
\hline Alona affinis & & & -0.845 & & & & & & & & 0.836 \\
\hline Alona quadrangularis & & & -0.828 & & & & & & 0.980 & & 0.853 \\
\hline Chydorus sphaericus & -0.971 & -0.971 & -0.971 & -0.883 & & & & & & -0.836 & \\
\hline
\end{tabular}


Table 7. Spearman's rank order correlation for diatoms (A), cladocerans (B), and physicochemical parameters of water of subsidence ponds formed during the peak of ore exploitation (DOWN).

\begin{tabular}{|c|c|c|c|c|c|c|c|c|c|c|c|c|c|}
\hline \multicolumn{14}{|c|}{ (A) Diatoms } \\
\hline Species & $\begin{array}{c}\text { Cd } \\
\text { Dissolved }\end{array}$ & $\begin{array}{c}\mathrm{Pb} \\
\text { Dissolved }\end{array}$ & $\begin{array}{c}\text { Zn } \\
\text { Dissolved }\end{array}$ & $\begin{array}{l}\text { Achnanthidium } \\
\text { minutissimum }\end{array}$ & $\begin{array}{c}\text { Nitzschia } \\
\text { palea } \\
\text { var. debilis }\end{array}$ & $\begin{array}{l}\text { Sellaphora } \\
\text { saugerresii }\end{array}$ & & & & & & & \\
\hline $\begin{array}{l}\text { Achnanthidium } \\
\text { minutissimum } \\
\text { Cocconeis }\end{array}$ & & 0.587 & & & & & & & & & & & \\
\hline $\begin{array}{l}\text { placentula var. } \\
\text { placentula }\end{array}$ & & 0.643 & & 0.866 & & & & & & & & & \\
\hline $\begin{array}{l}\text { Fragilaria } \\
\text { cf. famelica }\end{array}$ & 0.601 & & & & & & & & & & & & \\
\hline Melosira varians & & -0.641 & & & & & & & & & & & \\
\hline Nitzchia archibaldii & & & -0.629 & & & & & & & & & & \\
\hline Nitzschia linearis & & -0.579 & & & & & & & & & & & \\
\hline $\begin{array}{l}\text { Nitzschia palea } \\
\text { var. debilis }\end{array}$ & & & -0.750 & & & & & & & & & & \\
\hline $\begin{array}{l}\text { Sellaphora } \\
\text { saugerresii }\end{array}$ & & & -0.600 & & & & & & & & & & \\
\hline Staurosira venter & 0.600 & & 0.729 & & -0.632 & & & & & & & & \\
\hline $\begin{array}{l}\text { Thalasiosira } \\
\text { pseudonana }\end{array}$ & & & -0.646 & & & 0.774 & & & & & & & \\
\hline \multicolumn{14}{|c|}{ (B) Cladocerans } \\
\hline Species & Hardness & $\mathrm{NO}_{3}^{-}$ & $\mathrm{PO}_{4}{ }^{3-}$ & Cd Dissolved & $\begin{array}{l}\text { Craticula } \\
\text { buderi }\end{array}$ & $\begin{array}{l}\text { Fragilaria } \\
\text { bidens }\end{array}$ & $\begin{array}{c}\text { Navicula } \\
\text { cryptocephala }\end{array}$ & $\begin{array}{l}\text { Nitzchia } \\
\text { archibaldii }\end{array}$ & $\begin{array}{l}\text { Nitzschia } \\
\text { linearis }\end{array}$ & $\begin{array}{l}\text { Planothidium } \\
\text { lanceolatum }\end{array}$ & $\begin{array}{l}\text { Sellaphora } \\
\text { nigri }\end{array}$ & $\begin{array}{l}\text { Staurosirella } \\
\text { pinnata }\end{array}$ & $\begin{array}{c}\text { Surirella } \\
\text { brebisonii } \\
\text { var. kuetzingii }\end{array}$ \\
\hline \multicolumn{14}{|l|}{$\begin{array}{l}\text { Coronatella } \\
\text { rectangula }\end{array}$} \\
\hline Alonella exigua & & -0.640 & & & & 0.634 & -0.586 & & & & & & \\
\hline $\begin{array}{c}\text { Bosmina } \\
\text { longirostris }\end{array}$ & & & & & & & & 0.591 & & & & & \\
\hline $\begin{array}{l}\text { Ceriodaphnia } \\
\text { quadrangula }\end{array}$ & & -0.724 & 0.716 & & -0.623 & & & & & & & & \\
\hline $\begin{array}{l}\text { Chydorus } \\
\text { sphaericus }\end{array}$ & & & & & & & & & & -0.630 & & -0.619 & -0.672 \\
\hline Daphnia pulex & & & & 0.637 & & & & & & & & & \\
\hline Pleuroxus truncatus & -0.795 & & & & & & -0.714 & & & & 0.734 & & \\
\hline $\begin{array}{c}\text { Simocephalus } \\
\text { vetulus }\end{array}$ & & & & 0.733 & & & & & -0.603584 & & & & -0.641 \\
\hline
\end{tabular}


Table 8. Spearman's rank order correlation for diatoms (A) and cladocerans (B) from sediment core of subsidence pond formed during the peak of ore exploitation (DOWN). Taxa name: diatoms-Ach.min: Achnanthidium minutissimum; Ast.for: Asterionella formosa; Aul.gra: Aulacoseira granulata; Coc.neo: Cocconeis neodiminuta; Enc.ven: Encynema ventricosum; Enc.ces: Encyonopsis cesatii; Eun.min: Eunotia minor; Fra.gra: Fragilaria cf. gracilis; Gom.bre: Gomphonema brebissonii; Gom.par: G. parvulum; Gom.sag: G. sagitta; Mer.cir.var.cir: Meridion circulare var. circurale; Nav.ven: N. veneta; Nit.arc: N. archibaldii; Nit.cap: N. capitellata; Nit.gra: N. gracilis; Nit.pal.var.deb: N. palea var. debilis; Nit.sub: N. subacicularis; Pla.lan: Planothidium lanceolatum; Sel.nig: Sellaphora nigri; Sta.ven: Staurosira venter; Sur.ang: Surirella angusta; Sur.bre.var.kue: Surirella brebisonii var. kuetzingii; Tab.fas: Tabularia fasciculata; Uln.uln: U. ulna. Cladocerans-Alo.sp: Alona sp.; Alo.aff: A. affinis; Alo.qua: Alona quadrangularis; Alo.exc: Alonella excisa; Alo.nan: A. nana; Bos.lon: Bosmina longirostris; Cor.rec: Coronatella rectangula; Dap.sp: Daphnia sp.; Dap.cuc: D. cucullata; Gra.tes: Graptoleberis testudinaria; Ple.tru: Pleroxus truncatus.

\begin{tabular}{|c|c|c|c|c|c|c|c|c|c|c|c|c|c|c|c|c|c|c|c|c|c|c|c|c|c|c|}
\hline \multicolumn{27}{|c|}{ A. Diatoms } \\
\hline Species & งี & J & 2 & $\Xi$ & 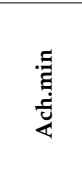 & 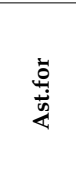 & 葋 & 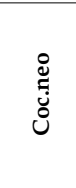 & 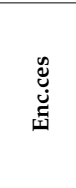 & 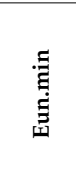 & 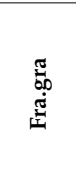 & 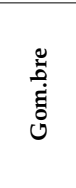 & 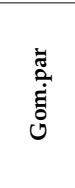 & 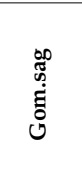 & 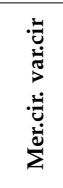 & 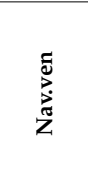 & $\underset{\breve{Z}}{\stackrel{\breve{Z}}{*}}$ & $\begin{array}{l}\text { శ్ } \\
\stackrel{\vec{z}}{z}\end{array}$ & 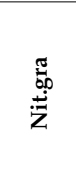 & 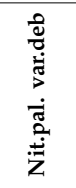 & $\begin{array}{l}\stackrel{0}{\bar{n}} \\
\stackrel{5}{\vec{z}}\end{array}$ & $\frac{\tilde{\sigma}}{\frac{\pi}{\tilde{J}}}$ & 㱔 & 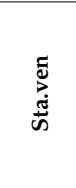 & 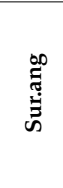 & 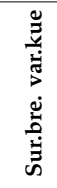 \\
\hline Ach.min & & 0.54 & & 0.54 & & & & & & & & & & & & & & & & & & & & & & \\
\hline $\begin{array}{l}\text { Ast.for } \\
\text { Aul.gra }\end{array}$ & 0.64 & 0.59 & & & & & 0.53 & & & & & & & & & & & & & & & & & & & \\
\hline Coc.neo & -0.52 & & & & & & & & & & & & & & & & & & & & & & & & & \\
\hline Enc.ven & & -0.57 & & & & & & & & & & & & & & & & & & & & & & & & \\
\hline Enc.ces & 0.54 & & 0.79 & & & & & & & & & & & & & & & & & & & & & & & \\
\hline Eun.min & & & $\begin{array}{c}-0.59 \\
0.60\end{array}$ & & & & & & & & & & & & & & & & & & & & & & & \\
\hline Fra.gra & 0.68 & 0.61 & 0.60 & & 0.58 & & & & & & & & & & & & & & & & & & & & & \\
\hline Gom.bre & -0.52 & -0.55 & -0.59 & -0.55 & -0.58 & & 0.62 & & & 0.82 & -0.59 & & & & & & & & & & & & & & & \\
\hline Gom.par & & & 0.58 & & & & & & & -0.54 & & & & & & & & & & & & & & & & \\
\hline Gom.sag & & & -0.59 & & & & & & & 1.00 & & 0.81 & -0.55 & & & & & & & & & & & & & \\
\hline Mer.cir.var.cir & 0.65 & & 0.69 & 0.69 & & & & & & -0.59 & & -0.55 & 0.62 & -0.59 & & & & & & & & & & & & \\
\hline Nav.ven & & & & 0.58 & & 0.61 & 0.53 & & & & 0.55 & & & & & & & & & & & & & & & \\
\hline Nit.arc & 0.57 & 0.62 & 0.52 & 0.58 & 0.83 & & & & & & 0.78 & & 0.57 & & & & & & & & & & & & & \\
\hline Nit.cap & 0.67 & & 0.56 & 0.52 & & & & -0.56 & & & & & 0.65 & & 0.73 & & & & & & & & & & & \\
\hline Nit.gra & 0.62 & 0.52 & 0.61 & & & & & & & & 0.72 & & & & & & & & & & & & & & & \\
\hline Nit.pal.var.deb & 0.61 & & & & 0.52 & & & -0.59 & & & & & 0.73 & & 0.62 & & 0.68 & 0.71 & & & & & & & & \\
\hline Nit.sub & & & 0.59 & & & & & & & 0.63 & & & & & & & & & 0.66 & & & & & & & \\
\hline Pla.lan & 0.56 & 0.54 & 0.65 & & & 0.58 & & & 0.66 & -0.55 & 0.62 & & 0.71 & -0.55 & & & 0.65 & & & 0.55 & & & & & & \\
\hline Sel.nig & 0.64 & 0.70 & 0.76 & 0.58 & 0.58 & & & -0.59 & 0.66 & -0.59 & & 0.58 & 0.80 & & & & & & 0.63 & 0.52 & & 0.87 & & & & \\
\hline Sta.ven & -0.60 & & -0.59 & & -0.65 & -0.63 & & & -0.54 & 0.59 & -0.60 & & -0.57 & 0.59 & & -0.55 & -0.78 & & -0.52 & -0.64 & & -0.76 & -0.76 & & & \\
\hline Sur.ang & & & 0.55 & & 0.66 & & & & 0.64 & & & -0.52 & 0.51 & & & & 0.52 & & & 0.52 & & & 0.62 & -0.57 & & \\
\hline Sur.bre.var.kue & 0.71 & 0.70 & 0.84 & 0.65 & & & & & 0.64 & -0.59 & & & 0.61 & -0.59 & 0.76 & & & 0.58 & & & & 0.68 & 0.69 & & 0.71 & \\
\hline Tab.fas & 061 & & 0.59 & -0.54 & & & & & & & & & & & & & & 071 & & 0.52 & 0.56 & & & & 061 & 066 \\
\hline
\end{tabular}


Table 8. Cont

\begin{tabular}{|c|c|c|c|c|c|c|c|c|c|c|c|c|c|c|c|}
\hline \multicolumn{16}{|c|}{ B. Cladocerans } \\
\hline Species & กี & J & 2 & $\Xi$ & 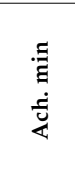 & $\begin{array}{l}\text { 泀 } \\
\text { 音 }\end{array}$ & 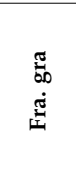 & 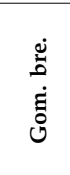 & $\begin{array}{l}\text { on } \\
\tilde{\omega} \\
\dot{\tilde{g}} \\
0 \\
0\end{array}$ & 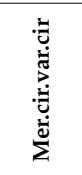 & $\frac{\tilde{\sigma}}{\frac{\pi}{\pi}}$ & 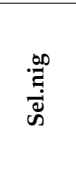 & $\begin{array}{l}\text { D̃ } \\
\text { D્j } \\
\tilde{\omega}\end{array}$ & 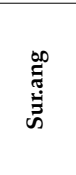 & 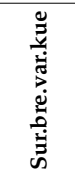 \\
\hline Alo.sp & & & -0.59 & & & 0.99 & & 0.80 & 1.00 & -0.59 & -0.55 & -0.59 & 0.59 & & -0.59 \\
\hline Alo.aff & & & -0.56 & & & 0.84 & & 0.65 & 0.84 & & -0.58 & -0.57 & 0.60 & & -0.62 \\
\hline Alo.exc & & & & & & 0.63 & & & 0.68 & & & & & & \\
\hline Alo.qua & & & & & & 0.73 & & 0.62 & 0.68 & & & & & & \\
\hline Correc & & & & & & 0.63 & & & 0.68 & & & & & & \\
\hline Alo.nan & & & & & & 0.73 & & 0.62 & 0.68 & & & & & & \\
\hline Bos.lon & & & & & & & & & & 0.61 & & & & & \\
\hline Dap.sp & & & & & & & & 0.80 & & & & & & & \\
\hline Dap.cuc & & & & & & 0.73 & & 0.62 & 0.68 & & & & & & \\
\hline Gla.tes & & -0.52 & -0.58 & -0.53 & -0.58 & 0.80 & -0.59 & 0.98 & 0.81 & -0.55 & & -0.59 & & -0.52 & \\
\hline Ple.tru & -0.52 & -0.54 & -0.60 & -0.55 & -0.58 & 0.84 & -0.59 & 0.99 & 0.85 & -0.57 & & -0.60 & & -0.53 & -0.52 \\
\hline
\end{tabular}


In the UP pond we found no correlation between heavy metals and cladocerans community in the water. In the water two species Moina micrura and Daphnia pulex were positively correlated with other physico-chemical variables. In the sediments of the UP pond a negative correlation was found only between heavy metals concentration and Cladocera species. Chydorus sphaericus negatively correlated with all heavy metals, but Alona affinis and A. quadrangularis negatively correlated with $\mathrm{Pb}$. Moreover, different species of diatoms positively correlated with cladocerans species probably reflecting trophic relationship (Tables 5B and 6B).

In the most polluted DOWN ponds a positive correlation between the two species of Cladocera (Daphnia pulex and Simocephalus vetulus) with dissolved Cd in the water, as well as a negative correlation between four taxa (Alona sp., A. affinis, Glaptoleberis testudinaria, Pleuroxus truncatus) and $\mathrm{Pb}$ in sediments were found. Cladocera were also negatively correlated with $\mathrm{Zn}, \mathrm{Cd}$, and $\mathrm{Cu}$ in the sediments. The correlation between diatoms and cladocerans taxa were both negative and positive, which may indicate more complex trophic relationships in these ponds (Tables 7B and 8B).

Generally, DOWN and UP ponds were statistically different with respect to plankton density and physico-chemicals of the water (Table 2). The U Mann-Whitney test showed significant differences in the density of plankton between UP and DOWN ponds $(Z=2.044452, p=0.040)$. The density was significantly higher in UP ponds. Moreover, $U$ Mann-Whitney test showed statistical differences in the cadmium concentration in the sediments $(Z=2.607971, p=0.009)$ between DOWN and UP ponds. Significant differences were found also between the number of diatom and cladoceran species $(\mathrm{Z}=3.152921, p=0.001)$.

Canonical correspondence analyses (CCA) revealed an influence of physicochemical variables and heavy metal concentrations in water and sediments on the distribution of diatoms and cladocerans communities. Statistically significant relationships were observed only in sediment cores (Figure 5).

The CCA model for diatoms and cladocerans in the pond sediments indicated statistically significant negative correlation with lead. The Monte Carlo permutation test showed statistical significance for both the first canonical axis $(\mathrm{F}=2.591, p=0.008)$ and for all canonical axes $(\mathrm{F}=2.174$, $p=0.006$ ). In the CCA analysis, the first axis explains $32.7 \%$, and the second axis $18.2 \%$ of the total variability of diatoms and claodocerans in the cores. The results of the stepwise forward selection of environmental variables showed that distribution of diatoms and cladocerans in the cores were related only to the content of $\mathrm{Pb}$ in the sediments and to the age of ponds. Figure 5 shows the group of organisms which were associated with a high content of $\mathrm{Pb}$ in sediments and the group of organisms which were associated with DOWN water bodies. 


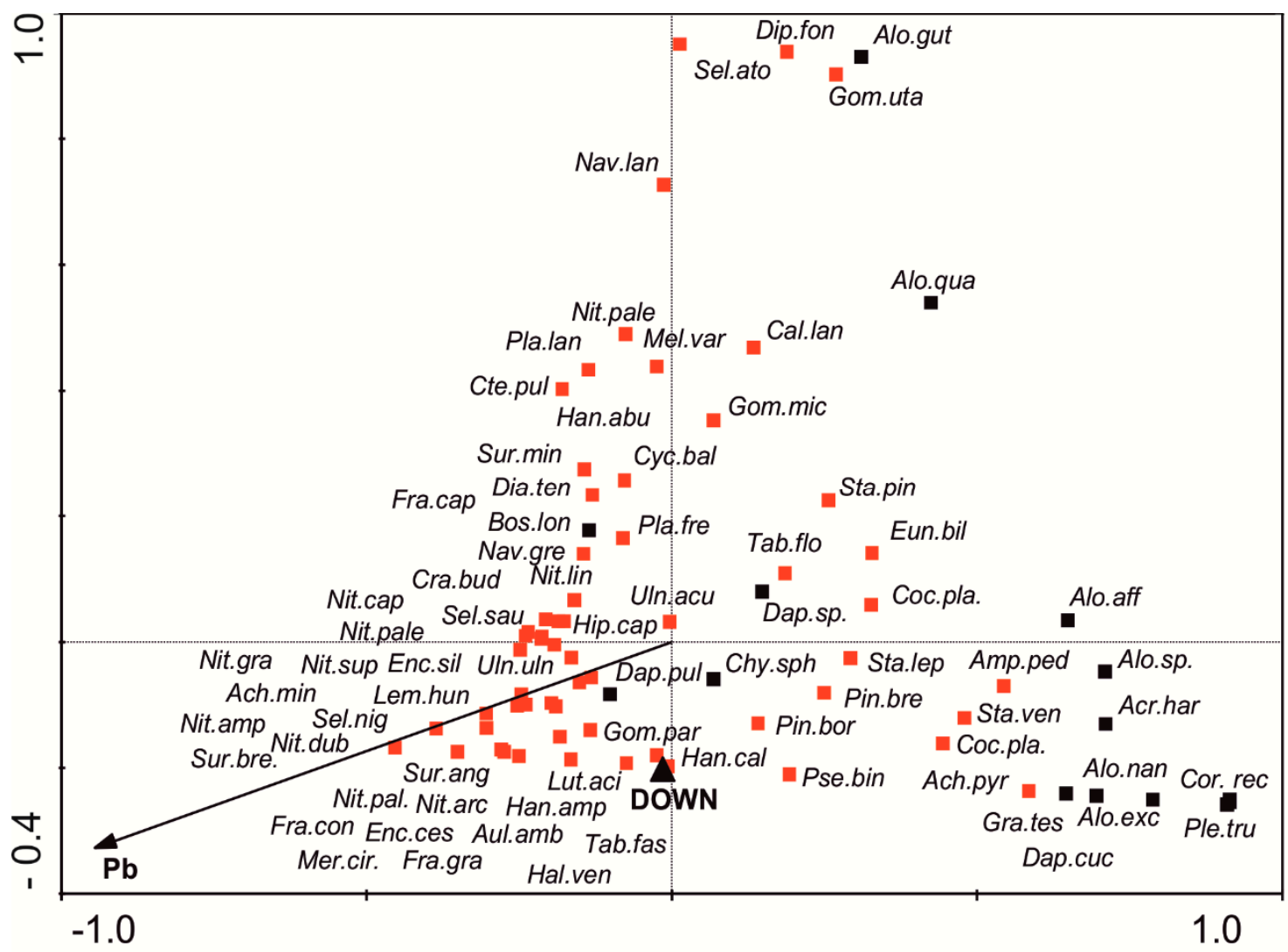

Figure 5. Canonical correspondence analysis (CCA) diagram for diatoms and cladocerans species. The biplot illustrates the relationship in sediments between the heavy metal concentration and diatoms and cladocerans. Taxa name: diatoms - Ach.min: Achnanthidium minutissimum; Ach.pyr: A. pyrenaicum; Amp.ped: Amphora pediculus; Aul.amb: Aulacoseira ambigua; Cal.lan: Caloneis lancettula; Coc.eug: Cocconeis euglypta; Coc.pla: C. placentula var. placentula; Cra.bud: Craticula buderi; Cte.pul: Ctenophora pulchella; Cyc.bal: Lindavia balatonis; Dia.ten: Diatoma tenuis; Dip.fon: Diploneis fontanella; Enc.sil: Encynema silesiacum; Enc.ces: Encyonopsis cesatii; Eun.bil: Eunotia bilunaris; Fra.cap: Fragilaria capucina; Fra.con: Staurosira construens; Fra.gra: Fragilaria cf. gracilis; Gom.mic: Gomphonema micropus; Gom.par: G. parvulum; Gom.uta: G. utae; Hal.ven: Halamphora veneta; Han.abu: Hantzschia abudans; Han.amp: H. amphioxys; Han.cal: Hantzschia calcifuga; Hip.cap: Hippodonta capitata; Mel.var: Melosira varians; Mer.cir: Meridion circulare; Lut.aci: Luticola acidoclinata; Lem.hun: Lemnicola hungarica; Nav.gre: Navicula gregaria; Nav.lan: N. lanceolata; Nit.amp: Nitzchia amphibia; Nit.arc: N. archibaldii; Nit.cap: N. capitellata; Nit.dub: N. dubia; Nit.gra: N. gracilis; Nit.lin: N. linearis; Nit.pac: N. paleacea; Nit.pad: N. palea var. debilis; Nit.pale: N. palea var. palea; Nit.sup: N. supralitorea; Pin.bor: Pinnularia borealis; Pin.bre: P. brebissonii; Pla.fre: Planothidium frequentissimum; Pla.lan: P. lanceolatum; Pse.bin: Pseudostaurosira binodis; Sel.ato: Sellaphora atomoides; Sel.nig: S. nigri; Sel.sau: S. saugeressi; Sta.ven: Staurosira venter; Sta.lep: Staurosirella leptostauron; Sur.ang: Surirella angusta; Sur.bre: Surirella brebisonii var. kuetzingii; Sur.min: S. minuta; Tab.flo: Tabellaria flocullosa; Tab.fas: Tabularia fasciculata; Uln.acu: Ulnaria acus; Uln.uln: U. ulna. Cladocerans - Acr.har: Acroperus harpae; Alo.sp.: Alona sp.; Alo.aff: A. affinis; Alo.gut: A. guttata; Alo.qua: A. quadrangularis; Alo.exc: Alonella excisa; Alo.nan: A. nana; Bos.lon: Bosmina longirostris; Chy.sph: Chydorus sphaericus; Cor.rec: Coronatella rectangula; Dap.sp: Daphnia sp.; Dap.cuc: D. cucullata; Dap.pul: D. pulex; Gra.tes: Graptoleberis testudinaria; Ple.tru: Pleroxus truncatus). Diatom taxa are marked in red color; cladocerans taxa are marked in black color.

\section{Discussion}

All the waters of the subsidence ponds on the Chechło River floodplain have higher values of conductivity and contents of ions $\mathrm{SO}_{4}{ }^{2-}, \mathrm{Cl}^{-}, \mathrm{PO}_{4}{ }^{3-}$ than small unpolluted water bodies in southern Poland [37]. However, these characteristics were similar to those in water bodies in the vicinity of 
another abandoned lead and zinc mine in Upper Silesia, in southern Poland [14]. Higher mean contents of above parameters in the UP pond (sites $\mathrm{CH} 5$ or $\mathrm{CH} 4$ ) were associated with the direct inflow of the Chechło River, contaminated by municipal sewages from the towns Trzebinia ( 20,000 inhabitants) and Chrzanów ( 40,000 inhabitants) in the upper section of the catchment [38]. Fluctuations of major ions and nutrients at site CH5 near the inflow of the Chechło River to the UP pond was probably mainly controlled by the river discharge because such changes were much lower in the downstream part of that pond. The differences of the same parameters in the water between sites $\mathrm{CH} 1-\mathrm{CH} 3$ of the DOWN ponds, are related to variable exchange rate between particular ponds and the Chechło River. The lowest concentrations of the above ions were found at site $\mathrm{CH} 3$ situated upstream from the inflow channel, in the most distant part of the pond. Inversely they were the highest at site $\mathrm{CH} 2$ of pond situated in proximity to the channel connecting the pond with the river. However, it should be emphasized that even during small floods all ponds (CH1-CH3) are flooded with river water.

Similarly to macroions, the total $\mathrm{Cd}, \mathrm{Pb}, \mathrm{Zn}$, and $\mathrm{Cu}$ concentrations in the studied waters were predominantly close to values from industrialized areas [39]; nevertheless, they were much lower than in aquatic systems polluted by active $\mathrm{Zn}$ and $\mathrm{Pb}$ mining $[40,41]$. The concentrations of dissolved $\mathrm{Cd}$ did not exceed permissible values for priority substances, while dissolved $\mathrm{Cu}$ and $\mathrm{Zn}$ were not higher than permissible country values for substances harmful to the aquatic environment [42]. Only the concentrations of dissolved $\mathrm{Pb}$ at sites $\mathrm{CH} 1-\mathrm{CH} 3$ and $\mathrm{CH} 5$ exceeded the average annual permissible values (AA-EQS, $1.2 \mu \mathrm{g} / \mathrm{dm}^{3}$ ) for priority substances, however they were still below maximum permissible values (Mac-EQS, $14 \mu \mathrm{g} / \mathrm{L}$, [42]). Sporadically higher total $\mathrm{Cd}, \mathrm{Pb}$, and $\mathrm{Zn}$ concentrations in the UP pond (site CH5), could be related to runoff from industrialized part of the catchment during higher rainfalls. Higher or maximum $\mathrm{Cd}$ (total and dissolved) and $\mathrm{Pb}$ (total and dissolved) concentrations noted in late summer (August) could be related to a degradation of organic matter in ponds. The largest maxima of total and dissolved $\mathrm{Cd}$ and $\mathrm{Pb}$ occurred in DOWN ponds ( $\mathrm{CH} 2$ and $\mathrm{CH} 3$ ) with the most contaminated sediments. A similar phenomenon was observed also in a fishpond of the nearby catchment and could reflect a release of these metals from sediments [39].

In contrary to the water, sediments were extremely contaminated by $\mathrm{Cd}, \mathrm{Pb}$, and $\mathrm{Zn}$ (according to values of $\mathrm{I}_{\mathrm{geo}}$, [35]) reaching levels found in water bodies affected by active and closed $\mathrm{Zn}$ and $\mathrm{Pb}$ mines $[14,40,41,43]$. This confirms that sediments of waters in mining areas act as long-term sinks for heavy metals $[44,45]$. Lower sediment contamination of the UP pond compared to the DOWN ponds (with some exceptions in the core RXII) is associated with the cessation of a discharge after closure of the mine. Low $\mathrm{Cd}, \mathrm{Pb}$, and $\mathrm{Zn}$ concentrations in the bottom strata of cores IV and XII indicate the lack of fluvial sediment deposition during mining era, before ponding of subsidence basins.

We studied changes of the planktonic and sedimentary diatoms over a temporal and spatial gradient of metal pollution in ponds affected by the operation of the ore mine because diatoms and cladocerans are excellent indicators of environmental change $[4,46,47]$. Most diatoms found in the plankton are tychoplanktic. That can be related to the small size of the ponds, which have the area not exceeding 4.5 ha of surface and $2 \mathrm{~m}$ depth [48]. However, diatom assemblages in $\mathrm{Zn}, \mathrm{Pb}, \mathrm{Cu}$, and $\mathrm{Cd}$ polluted waters were generally resistant to observed metal concentrations because of large similarity to populations from non-contaminated waters.

The sampled sites from UP and DOWN ponds were grouped on a dendrogram of similarities constructed for diatoms and Cladocera in plankton samples where the $\mathrm{CH} 4$ and $\mathrm{CH} 5$ (UP) are clearly different from CH1, CH2, and CH3 (DOWN) (Figure 4). In the UP pond (sites $\mathrm{CH} 5$ or $\mathrm{CH} 4$ ), the content of nutrients and total hardness (Table 1) is higher than in DOWN ponds because of the inflow of municipal sewages from nearby towns. The site $\mathrm{CH} 1$ was rich in Achnanthidium minutissimum, Gomphonema paroulum, Lemnicola hungarica, Nitzschia amphibia, and N. supralitorea. All of them belong to mesosaprobic and indifferent-mesotraphentic diatom group. Their abundance was highest at site $\mathrm{CH} 2$. Presence of some of these species, like Lemnicola hungarica, Nitzschia amphibia, and N. supralitorea indicate their adaptation to metal-contaminated waters. Achnanthidium minutissimum is well-known from metal contaminated waters [49], where this diatom clearly increases in population size [21,50]. 
Another diatom, Gomphonema parvulum is also present numerously under these conditions and similarly to Lemnicola hungarica and Nitzschia amphibia, it is considered a good indicator of strong water pollution. The example of over average dissolved $\mathrm{Cd}$ and $\mathrm{Zn}$ content is the site $\mathrm{CH} 5$ in the UP pond (Table 1) dominated by Gomphonema parvulum and Planothidium frequentissimum known as metal resistant [50]. Also, the site $\mathrm{CH} 3$ (DOWN) with the highest average dissolved Pb content (Table 1) was dominated by Achnanthidium minutissimum, Cocconeis placentula var. placentula, Gomphonema parvulum. Moreover, the above mentioned diatoms that adopted well to metal pollution belong to Cocconeis placentula var. placentula. Important diatoms in UP pond included also Melosira varians (Table 5), a metal-resistant diatom [50].

Generally, our results suggest that diatoms common in the ponds are resistant to moderate metal contamination in neutral and alkaline waters (Table 1) and even at sites $\mathrm{CH} 5, \mathrm{CH} 2$, or $\mathrm{CH} 4$ (Tables 1 and 2) with metals content raised over average. No shift toward domination of metal-resistant species was noted. This is supported also by other works stressing the presence of high content of hardness-causing cations (e.g., $\mathrm{Ca}^{2+}$ and $\mathrm{Mg}^{2+}$ ) as the factor mitigating the toxicity of metals in mine water [5,6]. Also, the dominance of more sensitive species (e.g., Gomphonema utae, Meridion circulare var. circulare, Planothidium lanceolatum and Staurosira venter) indicates good adaptation to metal-contaminated waters.

The cores from UP pond (RI and RIV) were dominated by mesosaprobous and meso-eutraphentic diatoms Gomphonema utae, Planothidium lanceolatum, and Staurosira venter. The diatom/metal correlations are significant for several taxa (Table 6A, Table 7A, and Table 8A). But the CCA analyses exhibited the highest (significant) importance of $\mathrm{Pb}$ concentrations on the distribution of investigated biota. Other metals were correlated to $\mathrm{Pb}$, however their impact was not significant. The diatoms most positively correlated to increase of $\mathrm{Pb}$ content were Achnanthidium minutissimum, Nitzschia amphibia, Sellaphora nigri, and Surirella brebisonii var. kuetzingii.

The increase in the number of these diatoms in our metal polluted sediments corresponds well with another finding. Achnanthidium minutissimum is generally considered as an indicator of metals pollution and is often reported as predominant in lotic waters exposed to heavy pollution by metals [50]. However, the status of this species as an indicator of this type of pollution has been discussed for a long time (diatoms attached to the substrate are more resistant but the ability of mobile diatoms makes them more susceptible to toxic substances) [20,51].

The presence of Sellaphora nigri (as Eolimna minima sensu auct. nonnull.), the most common benthic species in European freshwaters, is related to human-induced of eutrophication, heavy metal pollution, and nutrient-rich environments [20]. Surirella brebisonii var. kuetzingii and Nitzschia amphibia are also known to prefer metal-contaminated waters [50] and they are widely distributed diatoms in eutrophicated inland waters.

The taxa, in which relative abundance decreased with raised $\mathrm{Pb}$ content were e.g., Gomphonema utae, Staurosirella pinnata, Eunotia bilunaris, and Alona spp. (Figure 5). High number of Achnanthidium minutissimum (formerly called Achnanthes) associated with the decrease of Staurosira venter, Staurosirella leptostauron, and S. pinnata (formerly called Fragilaria) fits Hill et al.'s [52] opinion, that Fragilaria dominates at the less metal impacted sites when Achnanthes dominates at the more impacted sites. Moreover, the largest population of Staurosira venter (over 90\%), was observed in the core RXII-the least metal-polluted site (Figure 2). Several diatoms species are known as metal tolerant and pioneer, substrate-adherent species. Interesting and probably related to the neutral and alkaline reaction of waters is the almost complete lack of teratological forms. Many authors $[50,53]$ suggest their occurrence as indicator of strong metal pollution.

The Cladocera showed evident alteration after mine closure. Because of the short period of time after finishing of the exploitation and poorly identifiable post-mining sediment strata, this change could be identified from comparing the sediment and planktonic organisms. Generally, planktonic Cladocera is a more differentiated group ( 5 family and 13 taxa) than in sediment ( 3 families and 15 taxa). There was also a shift of dominant organisms from Alona sp. and Chydorus sphaericus in sediments 
to Daphnia pulex dominating the present-day planktonic taxa. Such a change was observed also in the Lake Orta (Italy) by Jeppensen et al. [54] where during the period of toxic discharge, the only dominant species were Chydorus sphaericus, scarce Bosmina, and rare Alona spp. whereas, the lake recovery was signified by a return of Daphnia pulex. The result achieved for the studied ponds is probably related to the fact that in the UP ponds the river water flows through the center of the pond, whereas the DOWN ponds are supplied with river water by side channels, and have stagnant water with abundant macrophytes. Leppänen $[4,10]$ in studies on mining pollution on Bosmina longirostris and Chydorus sphaericus underlined that those organisms tolerate mine water-impacted conditions. Some of authors mentioned also that $\mathrm{Ch}$. sphaericus is tolerant to water pollution in a wide range of abiotic conditions [55], but the long-term exposure of this species to $\mathrm{Cu}$ can reduce its rate of population growth [56,57]. We observed strong negative correlation between heavy metals $(\mathrm{Zn}, \mathrm{Cd}, \mathrm{Pb}, \mathrm{Cu})$ and Ch. sphaericus in subsidence pond formed after the mining cessation with sediments less contaminated by heavy metals.

In the present study the Shannon $\left(\mathrm{H}^{\prime}\right)$ index showed that much more diverse Cladocera communities occurred in plankton-but also in sediment cores of the subsidence pond formed after the mining cessation (UP) - than in older ponds (DOWN). These differences confirm the cladogram of similarities (constructed both for Cladocera and diatoms).

The change in abundance of some Cladocera correlates with water chemistry for: $\mathrm{SO}_{4}{ }^{2-}$ (Moina micrura), $\mathrm{NO}_{3}{ }^{-}$(Moina micrura, Daphnia pulex), $\mathrm{PO}_{4}{ }^{3-}$ (Daphnia pulex-UP) (Ceriodaphnia quadrangula-DOWN). A negative impact was noted only in DOWN ponds with $\mathrm{NO}_{3}{ }^{-}$and Alonella exigua and Ceriodaphnia quadrangula. The highest density of Daphnia pulex in water of DOWN ponds appear to be weakly impacted by heavy metals reflecting their adaptation to long-lasting contamination.

$\mathrm{Pb}$ was the most important metal that negatively impacted Cladocera in UP and DOWN ponds. $\mathrm{Pb}$ was not tolerated by Alona, Chydorus, Graptoleberis, and Pleuroxus. García-García et al. [58] confirm that high $\mathrm{Pb}$ concentration in water had a negative impact on Diaphanosoma, Moina, and Alona, excluding periods of raised water turbidity mitigating lead toxicity to cladocerans. In all subsidence ponds Alona and Chydorus were the dominant, and most abundant in studied sediments. The dominance of less sensitive species confirmed adaptation of cladocerans communities to chronic metal contamination [25]. Trophic relationship between diatoms and cladocerans were observed in sediment cores from UP and DOWN ponds. This is related to the ability of cladocerans to colonize in almost every type of freshwater.

Our research confirmed that heavy metal concentration in water from subsidence ponds had no influence on diatom and cladoceran communities, and recovery of the diatom and cladocerans communities is influenced by high heavy metal concentrations in the sediments of ponds in the river valley downstream of the mine waters discharge.

These results may be a key to understanding drivers for recovery of water ecosystems after long-term disturbances of their functioning.

\section{Conclusions}

This work presents important information on assessing the mine-water pollution impact on an aquatic ecosystem. In particular, it highlights the usefulness of diatoms and cladocerans as warning indicators of environmental change, supporting the use of multiple sediment proxies in paleolimnological pollution research. They provide information about the timing, direction, and magnitude of impacts caused by pollution events.

The analysis of plankton and remains of diatoms and cladocerans allowed to reconstruct pre-mining condition in the subsidence ponds. It also showed the conditions of the ponds when the $\mathrm{Zn}-\mathrm{Pb}$ mine was operating and after it had been closed. The occurrence of different ecological groups of diatoms and cladocerans (diversity in taxa and in density) in the subsidence ponds revealed the changes in water quality during mine operation and afterwards. 
Neolimnological studies describe the present conditions of biotic communities but paleolimnological information reveals past limnological conditions as an archive of environmental history.

Author Contributions: A.P. and D.C. were responsible for the research design. A.P., A.Z.W., E.S.-G., S.C., and D.C. laboratory analysis, analyzed the data, prepared drafted the text and figures. A.C. performed statistical analyses. All authors participated in discussions and editing. All authors have read and agreed to the published version of the manuscript.

Funding: This research was funded by National Science Center grant n. 2014/15/B/ST10/03862 and under Institute of Nature Conversation, Polish Academy of Sciences subvention.

Acknowledgments: We would like to thank Hanna Kuciel for their help with drawing works. We extend our thanks to Henri Dumont for the assistance with our text and in language editing. The researchers are a part of a grant titled: Reconstruction and prognosis of response of a river system affected by $\mathrm{Pb}-\mathrm{Zn}$ ore extraction to mining cessation.

Conflicts of Interest: The authors declare no conflict of interest.

\section{References}

1. Biesinger, K.; Christensen, G.; Fiandt, J. Effects of metal salt mixtures on Daphnia magna reproduction. Ecotoxicol. Environ. Saf. 1986, 11, 9-14. [CrossRef]

2. Norwood, W.; Borgmann, U.; Dixon, D.G.; Wallace, A. Effects of Metal Mixtures on Aquatic Biota: A Review of Observations and Methods. Hum. Ecol. Risk Assess. Int. J. 2003, 9, 795-811. [CrossRef]

3. Traudt, E.M.; Ranville, J.F.; Meyer, J.S. Acute toxicity of ternary Cd-Cu-Ni and Cd-Ni-Zn mixtures to Daphna magna: Dominant metal pairs change along a concentration gradient. Environ. Sci. Technol. 2017, 51, 4471-4481. [CrossRef]

4. Leppänen, J. Cladocera as Sentinels of Aquatic Mine Pollution. Ph.D. Thesis, Faculty of Biological and Environmental Sciences of the University of Helsinki, Helsinki, Finland, April 2019.

5. Yim, J.H.; Kim, K.-W.; Kim, S.D. Effect of hardness on acute toxicity of metal mixtures using Daphnia magna: Prediction of acid mine drainage toxicity. J. Hazard. Mater. 2006, 138, 16-21. [CrossRef]

6. Cooper, N.L.; Bidwell, J.R.; Kumar, A. Toxicity of copper, lead, and zinc mixtures to Ceriodaphnia dubia and Daphnia carinata. Ecotoxicol. Environ. Saf. 2009, 72, 1523-1528. [CrossRef]

7. Wollmann, K.; Deneke, R.; Nixdorf, B.; Packroff, G. Dynamics of planktonic food webs in three mining lakes across a pH gradient ( $\mathrm{pH} 2-4)$. Hydrobiologia 2000, 433, 3-14. [CrossRef]

8. Salonen, V.-P.; Tuovinen, N.; Valpola, S. History of Mine Drainage Impact on Lake Orijärvi Algal Communities, SW Finland. J. Paleolimnol. 2006, 35, 289-303. [CrossRef]

9. Hogsden, K.L.; Harding, J.S. Consequences of acid mine drainage for the structure and function of benthic stream communities: A review. Freshw. Sci. 2012, 31, 108-120. [CrossRef]

10. Leppänen, J.J. An overview of Cladoceran studies conducted in mine water impacted lakes. Int. Aquat. Res. 2018, 10, 207-221. [CrossRef]

11. Balistrieri, L.S.; Seal, R.; Piatak, N.M.; Paul, B.; Ii, R.R.S. Assessing the concentration, speciation, and toxicity of dissolved metals during mixing of acid-mine drainage and ambient river water downstream of the Elizabeth Copper Mine, Vermont, USA. Appl. Geochem. 2007, 22, 930-952. [CrossRef]

12. Ciszewski, D.; Aleksander-Kwaterczak, U.; Kubsik, U.; Kwandrans, J.; Pociecha, A.; Szarek-Gwiazda, E.; Tłoczek, I.; Waloszek, A.; Wilk-Wozniak, E. Interdisciplinary Investigations of Contamination Effects of Pond and Stream Waters Ans Sediments in the Matylda Catchment-An Attempt to Classification. In Interdisciplinary Researches in Natural Sciences; Zieliński, A., Ed.; Institute of GeographyJan Kochanowski University Kielce: Kielce, Poland, 2011; p. 29.

13. Wilk-Wozniak, E.; Pociecha, A.; Ciszewski, D.; Aleksander-Kwaterczak, U.; Walusiak, E. Phyto- and zooplankton in fishponds contaminated with heavy metal runoff from a lead-zinc mine. Oceanol. Hydrobiol. Stud. 2011, 40, 77-85. [CrossRef]

14. Ciszewski, D.; Aleksander-Kwaterczak, U.; Pociecha, A.; Szarek-Gwiazda, E.; Waloszek, A.; Wilk-Wozniak, E. Small effects of a large sediment contamination with heavy metals on aquatic organisms in the vicinity of an abandoned lead and zinc mine. Environ. Monit. Assess. 2013, 185, 9825-9842. [CrossRef] [PubMed] 
15. Sienkiewicz, E.; Gassiorowski, M. The evolution of a mining lake-From acidity to natural neutralization. Sci. Total. Environ. 2016, 557, 343-354. [CrossRef]

16. Smol, J.P. Pollution of Lakes and Rivers: A Paleoenvironmental Perspective, 2nd ed.; Wiley Blackwell: Hoboken, NJ, USA, 2008.

17. Kattel, G.; Battarbee, R.W.; Mackay, A.; Birks, H.J.B. Are cladoceran fossils in lake sediment samples a biased reflection of the communities from which they are derived? J. Paleolimnol. 2006, 38, 157-181. [CrossRef]

18. Moser, K.; Macdonald, G.; Smol, J.P. Applications of freshwater diatoms to geographical research. Prog. Phys. Geogr. Earth Environ. 1996, 20, 21-52. [CrossRef]

19. Anu, P.; Nandan, S.B.; Jayachandran, P.R.; Xavier, N.D.; Midhun, A.; Mohan, D. Toxicity effects of zinc on two marine diatoms, under varying macronutrient environment. Mar. Environ. Res. 2018, 142, 275-285. [CrossRef]

20. Morin, S.; Duong, T.T.; Herlory, O.; Feurtet-Mazel, A.; Coste, M. Cadmium Toxicity and Bioaccumulation in Freshwater Biofilms. Arch. Environ. Contam. Toxicol. 2007, 54, 173-186. [CrossRef]

21. Morin, S.; Corcoll, N.; Bonet, B.; Tlili, A.; Guasch, H. Diatom responses to zinc contamination along a Mediterranean river. Plant Ecol. Evol. 2014, 147, 325-332. [CrossRef]

22. Pandey, L.K.; Bergey, E. Metal toxicity and recovery response of riverine periphytic algae. Sci. Total Environ. 2018, 642, 1020-1031. [CrossRef]

23. Ciszewski, D. The past and prognosis of mining cessation impact on river sediment pollution. J. Soils Sediments 2018, 19, 393-402. [CrossRef]

24. Michailova, P.; Ilkova, J.; Szarek-Gwiazda, E.; Kownacki, A.; Ciszewski, D. Genome instability in Chironomus annularius sensu Strenzke (Diptera, Chironomidae): A biomarker for assessment of the heavy metal contaminants in Poland. J. Limnol. 2018, 7, 15-24. [CrossRef]

25. Pociecha, A.; Wojtal, A.Z.; Szarek-Gwiazda, E.; Cieplok, A.; Ciszewski, D.; Kownacki, A. Response of Cladocera Fauna to Heavy Metal Pollution, Based on Sediments from Subsidence Ponds Downstream of a Mine Discharge (S. Poland). Water 2019, 11, 810. [CrossRef]

26. Krammer, K.; Lange-Bertalot, H. Bacillariophyceae 1, Naviculaceae. In Süsswasserflora Von Mitteleuropa; Ettl, H., Gerloff, J., Heynig, H., Mollenhauer, D., Eds.; Band 2/1. Gustav Fisher Verlag: Stuttgart, Germany, 1986.

27. Krammer, K.; Lange-Bertalot, H. Bacillariophyceae 2, Bacillariaceae, Epithemiaceae, Surirellaceae. In Süsswasserflora Von Mitteleuropa; Ettl, H., Gerloff, J., Heynig, H., Mollenhauer, D., Eds.; Band 2/2. VEB Gustav Fisher Verlag: Jena, Germany, 1988.

28. Krammer, K.; Lange-Bertalot, H. Bacillariophyceae 3, Centrales, Fragilariaceae, Eunotiaceae. In Süsswasserflora Von Mitteleuropa; Ettl, H., Gerloff, J., Heynig, H., Mollenhauer, D., Eds.; Band 2/3. Gustav Fisher Verlag: Stuttgart/Jena, Germany, 1991.

29. Krammer, K.; Lange-Bertalot, H. Bacillariophyceae 4, Achnanthaceae, Kritishe Ergänzungen zu Navicula (Lineolatae) und Gomphonema. In Süsswasserflora Von Mitteleuropa; Ettl, H., Gerloff, J., Heynig, H., Mollenhauer, D., Eds.; Band 2/4. Gustav Fisher Verlag: Stuttgart/Jena, Germany, 1991.

30. Flößner, D. Die Haplopoda Und Cladocera Mitteleuropas; Backhuys Publisher: Leiden, The Netherlands, 2000.

31. Bledzki, L.; Rybak, J.I. Freshwater Crustacean Zooplankton of Europe: Cladocera E Copepoda (Calanoida, Cyclopoida) Key to Species Identification, with Notes on Ecology, Distribution, Methods and Introduction to Data Analysis; Springer Science and Business Media LLC: Berlin/Heidelberg, Germany, 2016.

32. Frey, D.G. Cladocera analysis. In Handbook of Holocene Palaeoecology and Palaeohydrology; Berglund, B.E., Ed.; Wiley: New York, NY, USA, 1986; pp. 667-692.

33. Frey, D.G. The taxonomy and biogeography of the Cladocera. Hydrobiologia 1987, 145, 5-17. [CrossRef]

34. Szeroczyńska, K.; Sarmaja-Korjonen, K. Atlas of Subfossil Cladocera from Central and Northern Europe; Towarzystwo Przyjaciół Dolnej Wisły: Świecie, Polska, 2007; pp. 1-84.

35. Müller, G. Die Schwermetallbelastung der Sedimente des Neckars und seiner Nebenflüsse: Eine Bestandaufnahme. Chem. Ztg. 1981, 6, 157-164.

36. Turiekian, K.K.; Wedepohl, K.H. Distribution of the elements in some major units of the earth's crusts. Geol. Soc. Am. Bull. 1961, 72, 175-192. [CrossRef]

37. Szarek-Gwiazda, E.; Mazurkiewicz-Boron, G.; Gwiazda, R.; Urban, J. Chemical variability of water and sediment over time and along a mountain river subjected to natural and human impact. Knowl. Manag. Aquat. Ecosyst. 2018, 419, 1-14. [CrossRef] 
38. Ciszewski, D. Source of pollution as a factor controlling distribution of heavy metals in bottom sediments of Chechło River (south Poland). Environ. Earth Sci. 1997, 29, 50-57. [CrossRef]

39. Szarek-Gwiazda, E.; Ciszewski, D. Variability of heavy metal concentrations in waters of fishponds affected by the former lead and zinc mine in Southern Poland. Environ. Prot. Eng. 2017, 43, 121-136. [CrossRef]

40. Adamu, C.; Nganje, T. Heavy Metal Contamination of Soil and Surface Water in the Arufu Lead-Zinc Mining District, Middle Benue Trough, Nigeria. Ghana Min. J. 2011, 12, 17-23. [CrossRef]

41. Ilkova, J.; Michailova, P.; Szarek-Gwiazda, E.; Kownacki, A.; Ciszewski, D. Prodiamesa olivacea Meigen and Prodiamesa bureshi Michailova (Diptera, Chironomidae, Prodiamesinae) as a candidate for accessing the genotoxicity of trace metals in fluvial sediment. Environ. Monit. Assess. 2018, 190, 542. [CrossRef]

42. Regulation of the Ministry of Environment of 21 July 2016 (Dz.U. 2016, poz 1187). Rozporzadzeniu Ministra Środowiska z Dnia 21 Lipca 2016 r. w Sprawie Sposobu Klasyfikacji Stanu Jednolitych Części Wód Powierzchniowych oraz Środowiskowych norm Jakości dla Substancji Priorytetowych. Dziennik Ustaw 2016, poz. 1187. Available online: http://prawo.sejm.gov.pl/isap.nsf/download.xsp/WDU20160001187/O/ D20161187.pdf (accessed on 5 May 2016).

43. Audry, S.; Schäfer, J.; Blanc, G.; Jouanneau, J.-M. Fifty-year sedimentary record of heavy metal pollution (Cd, $\mathrm{Zn}, \mathrm{Cu}, \mathrm{Pb}$ ) in the Lot River reservoirs (France). Environ. Pollut. 2004, 132, 413-426. [CrossRef] [PubMed]

44. Ciszewski, D. Pollution of the Mała Panew sediments with heavy metals: Part, I. Effect of changes in river bed morphology. Pollut. J. Environ. Stud. 2004, 13, 589-595.

45. Lukin, A.; Dauvalter, V.; Kashulin, N.; Yakovlev, V.; Sharov, A.; Vandysh, O. Assessment of copper-nickel industry impact on a subarctic lake ecosystem. Sci. Total Environ. 2003, 306, 73-83. [CrossRef]

46. Hofmann, G.; Werum, M.; Lange-Bertalot, H. Diatomeen im Süßwasser-Benthos Von Mitteleuropa; Gantner Verlag: Ruggell, Liechtenstein, 2011.

47. Stevenson, R.J.; Pan, Y.; Van Dam, H. Assessing environment al conditions in rivers and streams with diatoms. In The Diatoms: Applications for the Enviromental and Earth Sciences; Smol, J.P., Stoermer, E.F., Eds.; Cambridge Univ. Press: Cambridge, UK, 2010; pp. 57-85.

48. Ciszewski, D.; Cichoń, S.; Wojtal, A. Zapis zakończenia eksploatacji rud Zn-Pb w osadach rzeki i małych zbiorników wodnych. Prace i Studia Geograficzne 2018, 63, 119-132.

49. Cantonati, M.; Angeli, N.; Virtanen, L.; Wojtal, A.Z.; Gabrieli, J.; Falasco, E.; Lavoie, I.; Morin, S.; Marchetto, A.; Fortin, C.; et al. Achnanthidium minutissimum (Bacillariophyta) valve deformities as indicators of metal enrichment in diverse widely-distributed freshwater habitats. Sci. Total Environ. 2014, 475, 201-215. [CrossRef]

50. Morin, S.; Cordonier, A.; Lavoie, I.; Arini, A.; Blanco, S.; Duong, T.T.; Tornés, E.; Bonet, B.; Corcoll, N.; Faggiano, L.; et al. Consistency in Diatom Response to Metal-Contaminated Environments. In The Handbook of Environmental Chemistry; Guasch, H., Ginebreda Geiszinger, A.A., Eds.; Handbook Env. Chem. 19; Springer Science and Business Media LLC: Berlin/Heidelberg, Germany, 2012; pp. 117-146.

51. Wetzel, C.E.; Ector, L.; Van De Vijver, B.; Compère, P.; Mann, D. Morphology, typification and critical analysis of some ecologically important small naviculoid species (Bacillariophyta). Fottea 2015, 15, 203-234. [CrossRef]

52. Hill, B.H.; Willingham, W.T.; Parrish, L.P.; McFarland, B.H. Periphyton community responses to elevated metal concentrations in a Rocky Mountain stream. Hydrobiologia 2000, 428, 161-169. [CrossRef]

53. Lavoie, I.; Hamilton, P.B.; Morin, S.; Tiam, S.K.; Kahlert, M.; Gonçalves, S.; Falasco, E.; Fortin, C.; Gontero, B.; Heudre, D.; et al. Diatom teratologies as biomarkers of contamination: Are all deformities ecologically meaningful? Ecol. Indic. 2017, 82, 539-550. [CrossRef]

54. Jeppesen, E.; Leavitt, P.R.; De Meester, L.; Jensen, J.P. Functional ecology and palaeolimnology: Using cladoceran remains to reconstruct anthropogenic impact. Trends Ecol. Evol. 2001, 16, 191-198. [CrossRef]

55. Belyaeva, M.; Deneke, R. Colonization of acidic mining lakes: Chydorus sphaericus and other Cladocera within a dynamic horizontal pH gradient ( $\mathrm{pH} 3-7)$ in Lake Senftenberger See (Germany). Hydrobiologia 2007, 594, 97-108. [CrossRef]

56. Koivisto, S.; Ketola, M.; Walls, M. Comparison of five cladoceran species in short- and long-term copper exposure. Hydrobiologia 1992, 248, 125-136. [CrossRef] 
57. Burton, S.M.; Rundle, S.D.; Jones, M.B. The relationship between trace metal contamination and stream meiofauna. Environ. Pollut. 2001, 111, 159-167. [CrossRef]

58. García, G.G.; Nandini, S.; Sarma, S.S.S. Turbidity mitigates lead toxicity to cladocerans (Cladocera). Ecotoxicology 2006, 15, 425-436. [CrossRef] [PubMed]

(C) 2020 by the authors. Licensee MDPI, Basel, Switzerland. This article is an open access article distributed under the terms and conditions of the Creative Commons Attribution (CC BY) license (http://creativecommons.org/licenses/by/4.0/). 